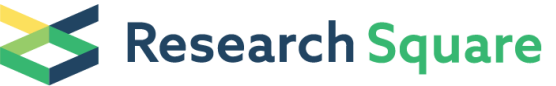 \\ Preprints are preliminary reports that have not undergone peer review. \\ They should not be considered conclusive, used to inform clinical practice, or referenced by the media as validated information.
}

\section{Molecular Epidemiology of Cryptosporidium spp. in an Agricultural Area of Northern Vietnam: A Community Survey}

\section{Hanako Iwashita ( $\square$ iwashita.hanako@twmu.ac.jp )}

Tokyo Women's Medical University: Tokyo Joshi lka Daigaku https://orcid.org/0000-0002-7158-9487

\section{Taichiro Takemura}

Vietnam Research Station, Center for Infectious Research in Asia and Africa, Institute of Tropical Medicine, Nagasaki University

\section{Asako Tokizawa}

Research Center for Child Mental Development, Hamamatsu University School of Medicine

\section{Tetsuhiro Sugamoto}

International Programs, Japan Anti-Tuberculosis Association

\section{DINH THIEM VU}

National Institute of Hygiene and Epidemiology

\section{Hai Tuan Nguyen}

National Institute of Hygiene and Epidemiology

\section{Duc_Tho PHAM}

Vienmec International Hospital

\section{Anh Pham Hong Quynh}

Vietnam Research Station, Center for Infectious Disease Research in Asia and Africa, Institute of Tropical Medicine, Nagasaki University

\section{Hang Doan Thi}

Vietnam Research Station, Center for Infectious Disease Research in Asia and Africa, Institute of Tropical Medicine, Nagasaki University

\section{$\mathrm{Na}$ Ly Tran}

Division of Bio-Medical Science \& Technology, Korea University of Science and Technology

\section{Tetsu Yamashiro}

Department of Bacteriology, Graduate School of Medicine, University of the Ryukyus

\section{Research}

Keywords: Cryptosporidium spp., Cryptosporidium canis, Cryptosporidium hominis, Cryptosporidium suis, zoonotic transmission, zooanthroponotic transmission, Northern Vietnam, dog, pig, humans

Posted Date: December 4th, 2020

DOl: https://doi.org/10.21203/rs.3.rs-117768/v1 
License: (a) (i) This work is licensed under a Creative Commons Attribution 4.0 International License. Read Full License 


\section{Abstract}

\section{Background}

Cryptosporidium spp. is a protozoan parasite with worldwide distribution that causes cryptosporidiosis in humans and other animals. In the countryside of northern Vietnam, where free-roaming livestock are widespread, cryptosporidiosis is an important zoonotic disease. However, there have been few studies of cryptosporidiosis in Southeast Asia from the perspective of zoonotic disease epidemiology. The purpose of this study was to investigate the occurrence of Cryptosporidium infection in both humans and animals and to gain an awareness of the potential threat posed by this zoonotic infection in northern Vietnam.

\section{Methods}

We conducted a community survey to collect information about cases of diarrhea in an agricultural area of northern Vietnam. For this study, a total of 2715 samples ( 2120 human diarrheal samples, 471 non-diarrheal human samples, and 124 animal stool samples) were collected. A direct immunofluorescence assay (DFA) was used to detect Cryptosporidium spp. oocysts in concentrated stool samples by observation under a fluorescent microscope. DNA extraction, PCR amplification of the three genes (COWP, SSU-rRNA, and GP60), and sequencing analysis were performed to identify Cryptosporidium spp.

\section{Results}

Of 2715 samples, 15 samples (10 diarrheal samples, 2 non-diarrheal samples, and 3 animal stool samples) tested positive by PCR for the COWP gene. Three species of Cryptosporidium spp. were detected; $C$. canis (from six human diarrheal samples, two human non-diarrheal samples, and one dog sample); $C$. hominis (from four human diarrheal samples); and $C$. suis (from two pig samples). In terms of $C$. hominis, the GP60 subtype leA12G3T3 was detected in all four human diarrheal samples.

\section{Conclusions}

Although the number of positive samples was very small, our epidemiological data showed that the emerging pattern of each of the three species (C. canis, $C$. hominis, and $C$. suis) was different at this study site. For example, zoonotic transmission of $C$. canis, between dogs and humans was suspected. Further studies are needed to assess the risk of oocyst contamination in the wider environment, including water, in this study area.

\section{Background}

Worldwide, Cryptosporidium is considered an important protozoan parasite that causes gastroenteritis in a wide range of animals, including humans [1-4]. Cryptosporidiosis can lead to severe problems in immunocompromised or young hosts, in both animals and humans [5]. In the livestock farming industry, cryptosporidiosis can cause great economic losses due to weight loss and delayed growth in young animals and decreased production in adult animals [1]. In humans, infection with Cryptosporidium spp. can mean not only severe diarrhea but also death in patients with HIV/AIDS, patients who have received an organ transplant, and patients on immunosuppressants [6]. So far, no effective vaccines are available to prevent cryptosporidiosis in humans or in livestock [7]. Prevention and control measures are therefore essential for the 
protection of vulnerable groups, such as young children and severely immunocompromised individuals, as there are only a few safe and effective therapeutic options available.

In countryside of Vietnam, where livestock live closely with humans, Cryptosporidium transmission to humans can easily occurs via the interaction between animals and humans [8]. People can become infected by ingesting infective Cryptosporidium oocysts through the fecal-oral route, including directly from infected persons (human-to-human) or animals (animal-to-human), or indirectly through the consumption of contaminated drinking water or food [1]. A distinctive pattern of transmission in the countryside of Vietnam may be environmental contamination through infected manure, which is applied to the land. It has been reported that Asia has the highest oocyst load from livestock manure compared with the loads seen on other continents [9]. One of the reasons may be climate. For example, Cryptosporidium oocysts can be maintained for a long time in Vietnam because the climate is warm and humid in the summertime, which is suitable for the survival of oocysts [10]. Also, Vietnam has a rainy season with heavy rainfall, which may facilitate Cryptosporidium oocysts spreading in the environment, leading to infections in humans and animals [11]. Previous studies conducted in Southeast Asia, including in Vietnam, have shown that there is the possibility of human Cryptosporidium infections originating from contaminated environmental sources [12]. To prevent and control cryptosporidiosis in agricultural areas, it is important to improve our understanding of environmental transmission routes of Cryptosporidium. An integrated genotyping approach would help in identifying sources of infection and routes of transmission under Vietnamese agricultural conditions [8].

Currently, many species and genotypes of Cryptosporidium spp. have been described, in a wide range of animals, livestock, and wild animals [2, 3, 5, 12]. It was previously thought that each species of Cryptosporidium had a limited host range and was able to infect only a single host or closely related host species [3]. However, according to the latest data it is likely that each species possesses a very broad range of hosts [3]. Molecular epidemiological surveillance-based studies have revealed an expanded host range of each Cryptosporidium spp. and their geographic distribution [13]. However, there is a scarcity of information about the molecular epidemiology of Cryptosporidium spp. in Vietnam. Therefore, our objective was to investigate the occurrence of Cryptosporidium infections and the potential for transmission of Cryptosporidium spp. between animals and humans in Vietnam.

\section{Methods}

\section{Sampling (diarrheal sample collection from humans, non-diarrheal sample collection from humans, and stool sample collection from animals)}

The study area $\left(12 \mathrm{~km}^{2}\right)$ was a typical agricultural area in northern Vietnam, located about $75 \mathrm{~km}$ southeast of Hanoi. A total 2715 samples, comprising both human and animal stools, were collected using three sampling methods in Hien Khanh commune, Vu Ban district, Nam Dinh province, Vietnam. Through prospective collection for human diarrheal samples (October 2014 to March 2017), 2120 human diarrheal samples were collected from 1508 residents from 311 randomly selected households that had children of less than 5 years of age. (The detailed information is in Iwashita et al. submitted to BMC public health). Through cross-sectional collection for human non-diarrheal samples (September to October 2014), 471 human non-diarrheal samples were collected from 471 residents from 105 households, which were randomly selected from 311 households used for 
diarrheal sampling (The detailed information is in Sugamoto et al. submitted to Parasite Epidemiol. Control.). Cross-sectional collection of animal stool samples (August to October 2015) yield 124 animal stool samples from animals (without clinical signs) present in this study area, such as buffalos, dairy and beef cattle, pigs, dogs, and monkey and boar (The detailed information is in Iwashita et al. submitted to Parasite Epidemiol. Control.).

\section{Procedure of the detection of Cryptosporidium spp.}

For all 2715 samples (2120 human diarrheal samples, 471 human non-diarrheal samples, and 124 animal stool samples), the formalin-ether sedimentation technique (406th Medical General Laboratory; MGL) was used to concentrate protozoal oocysts in stool samples [14]. A direct Immunofluorescence assay (DFA) using antibodies tagged with the fluorescent markers, DyLight488 (ARK Fluor Ab C/G-DyLight488, ARK Resource Co., Ltd.) was applied to detect oocysts of Cryptosporidium spp. in the concentrated stool samples under a fluorescent microscope (Eclipse 90i, Nikon Instruments Inc.) [14]. Using antibodies tagged with fluorescent markers, DyLight488 is able to target not only Cryptosporidium spp. but also Giardia spp. Detection by DFA was simultaneously conducted in previous study to detect Giardia spp. using the same 2715 samples (Iwashita et al. submitted to Parasite Epidemiol. Control.). In terms of human stool samples (2120 diarrheal samples and 471 non-diarrheal samples), any samples positive for Cryptosporidium spp. by DFA had their DNA extracted for PCR and sequencing analysis. All 124 animal stool samples, including those positive or negative for Cryptosporidium spp. by DFA, had DNA extracted for PCR and sequencing analysis.

\section{DNA extraction}

Stool samples concentrated using the MGL technique were washed twice with sterile water and then ten freezethaw cycles (freezing in liquid nitrogen for $5 \mathrm{~min}$ and heating at $95^{\circ} \mathrm{C}$ for $5 \mathrm{~min}$ ) were performed to disrupt the oocysts. DNA was then extracted using a PowerSoil DNA Isolation Kit (MoBio Laboratories Inc., Carlsbad, Calfolnia) following the manufacturer's instructions and stored at $-20^{\circ} \mathrm{C}$ prior to use. To avoid crosscontamination between animal and human samples, both samples was separately treated.

\section{PCR analysis of the three genes (COWP, SSU-rRNA, GP60)}

Fragment of the oocyst wall protein (COWP) gene [15] and the small-subunit ribosomal RNA (SSU-rRNA) gene $[16,17]$ were amplified using nested PCR protocols for the identification of Cryptosporidium species (Table 1). Fragments of the 60-kDa glycoprotein (GP60) gene was also amplified using nested-PCR protocols [18, 19] for further subtyping of Cryptosporidium species, especially $C$. homins and C. parvum (Table 1). PCR was performed using a MyCycler thermal cycler (Bio-Rad, Hercules, USA). Each $25 \mu \mathrm{L}$ reaction mixture contained GoTaq Green Master Mix (containing Go Taq ${ }^{\circledR}$ DNA Polymerase, dNTP mixture, Green Go Taq Reaction Buffer, $\mathrm{MgCl}$; Promega) with 5\% dimethyl sulfoxide (Sigma-Aldrich, USA) and $0.4 \mathrm{mg} / \mathrm{ml}$ BSA (Sigma-Aldrich, USA). Two types of nested-PCR protocols were used to prepare the SSU-rRNA $[16,17]$ and GP60 genes $[18,19]$ (Table 1). All samples were amplified using three nested-PCR protocols targeting the COWP [15] and SSU-rRNA genes $[16,17]$ (Table 1) and all second PCR products were evaluated by a $1.5 \%$ agarose gel electrophoresis. In terms of the COWP gene [15], both the first and second PCR products were additionally evaluated to identify longer sequences. For all the PCR reactions, Cryptosporidium-positive DNA and distilled water were used as positive and negative controls, respectively. 


\section{Sequencing and phylogenetic analyses.}

All positive PCR products were purified using an MonoFas DNA Purification Kit (GL Sciences, Tokyo, Japan) and sequenced in both directions (with forward and reverse primers) using an ABI 3730xI DNA analyzer (Applied Biosystems, Foster City, CA, USA). All sequences including SSU-rRNA, COWP and GP60 were analyzed using the BLAST program (http://blast.ncbi.nih.gov/BLAST.cgi) for homology searches. Cryptosporidium species reference sequences were obtained from GenBank to ensure accurate species/genotype and subtype identity, and reports of human cases were searched [20-26] (Additional file 1: Table S1). Phylogenetic analyses of the COWP and SSU-rDNA sequences of different Cryptosporidium species and genotypes were performed using MEGA (Molecular Evolutionary Genetic Analysis) 6.0 software (http://www.megasoftware.net/).

\section{Results}

A total of 2591 human stool samples (2120 human diarrheal samples and 471 human non-diarrheal samples) were screened with DFA. Of these, 77 human diarrheal samples and 11 human non-diarrheal samples were positive for Cryptosporidium spp. DNA was extracted from these samples for PCR analysis. All 124 animal stool samples, regardless of whether they were positive or negative for Cryptosporidium spp. by DFA had DNA extracted for PCR analysis (Fig. 1).

Through our sampling methods, only fifteen samples (ten human diarrheal samples, two human non-diarrheal samples, and three animal stool samples) were found to be positive for Cryptosporidium spp. by PCR (Table 2). The patterns of Cryptosporidium infection caused by $C$. canis, $C$. hominis and $C$. suis at our study site became clear. Cryptosporidium canis was detected from human non-diarrheal (Fig. 2) and diarrheal samples (Fig. 3), and dog stool samples (Fig. 4区), while C. suis was only detected in pigs (Fig. 4『). Cryptosporidium hominis was only detected in human diarrheal samples (Fig. 3). Through our prospective diarrhea sampling, four samples that were positive for $C$. homins were coincidentally detected from two neighboring households at the same time (Fig. 3区). The six samples positive for $C$. canis, on the other hand, were sporadically detected without any obvious patterns of occurrence. The $C$. hominis-positive cases were aged 11, 15, 37 and 70 years (Table 2). There were no samples from children aged less than 5 years, the group most vulnerable to severe diarrhea. On the other hands, the age of $C$. canis-positive cases were 1, 2, 5, 6, 7, and 26 years for diarrheal samples and 2 years for the two non-diarrheal samples (Table 2). No samples from buffalos or dairy and beef cattle were positive for Cryptosporidium spp. Primers targeting the COWP gene had a higher detection rate (15/15) than primers targeting the SSU-rRNA gene (9/15) (Table 2). Samples in which $C$. canis and $C$. suis were identified by PCR using the COWP gene and/or the SSU-rRNA gene, failed to amplify any DNA using primers targeting the GP60 gene, because the GP60 primers were more specific for $C$. hominis. In terms of the COWP and SSU-rRNA genes, the phylogenetic tree constructed using MEGA software is shown in Figs. 5 and 6 . Bootstrap values were obtained using 1000 pseudo-replicates; those $>50 \%$ are shown on nodes. The evolutionary distances were computed using the Kimura-2 parameter method [27]. GenBank accession numbers are shown before the species names in Figs. 5 and 6 and Additional file 1: Table S1.

\section{Molecular diagnosis using the COWP gene}

Good quality sequencing data of COWP gene were available for the 15 isolates. Phylogenetic analysis could identify three species of Cryptosporidium spp. (Fig. 5). Two isolates (from pig stool samples) assigned to $C$. 
suis, exhibited $100 \%$ identity with the reference sequence AF266270.1, between position 359 to 712 . Four isolates (four human diarrheal samples) assigned to the $C$. hominis, exhibited $100 \%$ identity with the reference sequence AF266265.1, while three isolates comprised 506 bp between positions 359 to 864 and one isolate (CDS_1788) comprised 354 bp between positions 359 to 712. Nine isolates (one dog sample, six human diarrheal samples, and two human non-diarrheal samples) were assigned to $C$. canis. One of them exhibited 100\% identity with the reference sequence AF266274.1, between 17 to 370 (Ani_140). The remaining eight isolates differed by one or two single nucleotide polymorphisms (SNPs) with it, although the amplified product sizes were different: CDS_263 and CDS_449 were 354 bp, while the others are 506 bp (Table 3). The unique sequences described here have been deposited in the GenBank database under accession numbers LC503969 to LC503972 (Table 3). Details of the results using COWP gene are shown in Additional file 2: Table S2.

\section{Molecular diagnosis using the SSU-rRNA gene}

Good-quality sequencing data of SSU-rRNA gene were available for the nine isolates. Phylogenetic analysis could clearly distinguish three species of Cryptosporidium spp., the same as the analysis based on the COWP gene (Fig. 5, 6). Two isolates (from pig stool samples) assigned to $C$. suis exhibited $100 \%$ identity with the reference sequence AB449824, between position 98 to 638. Three isolates (three human diarrheal samples) assigned to the $C$. hominis exhibited $100 \%$ identity with the reference sequence AF108865.1, while two isolates comprised 543 bp between positions 313 to 855 and one isolate (CDS_1788) comprised 735 bp between 241 to 975. Four isolates (one dog sample, two human non-diarrheal samples, and one human diarrheal sample) assigned to $C$. canis showed 100\% identity with the reference sequence AB210854.1, between 312 to 846 (535 bp). Details of the results using the SSU-rRNA gene are shown in Additional file 3: Table S3.

\section{Molecular diagnosis using the GP60 gene}

In this study, all four $C$. hominis-positive samples using the COWP and/or SSU-rRNA genes were successfully subtyped using the GP60 gene (Table 2). One subtype from all four isolates, leA12G3T3 was identified according to the scheme described by Xiao [28]. Other Cryptosporidium-positive samples using COWP and/or SSU-rRNA gene were not amplified with primers for the GP60 gene. Details of the results using the GP60 gene are shown in Additional file 4: Table S4.

\section{Discussion}

Although Cryptosporidium infection was not highly prevalent among human or animal samples tested from this study site, the potential for zoonotic transmission of $C$. canis from dogs to humans and vice versa was apparent. We found no positive samples in cattle or buffalos we tested, although zoonotic transmission from these species has been reported by researches in other areas studied, such as China [29]. Instead, in our study area, there were samples positive for Cryptosporidium in dogs, pigs and humans. Although most cases of cryptosporidiosis caused by $C$. canis globally have been reported in dogs, some cases have been reported in humans, according to other studies and our results [30,31]. For example, in Siem Reap, northwest Cambodia, human stool samples collected from five patients attending the out-patient clinic or admitted to hospital were positive for $C$. canis [32]. The dogs at this study site were free roaming, as is commonly the case in the countryside of Vietnam, and had close relationship with humans. The infection may occur either inside or 
outside of households. Human and animal feces can easily contaminate the environment, including with Cryptosporidium spp., due to a lack of a sewage system at the study site.

In previous studies conducted in Vietnam and surrounding countries, Cryptosporidium infections have been identified in animals and/or humans using methods such as microscopic analysis, immunofluorescence, enzyme-linked immunosorbent assays, and PCR [32, 33, 42-50, 34-41]. Most studies applied molecular methods to identify species and genotypes of Cryptosporidium (Table 4). In Vietnam and surrounding countries or areas (e.g., Laos, Cambodia, the southern provinces of China), the following species of Cryptosporidium were detected (with host animals in parentheses): C. andersoni (dairy cattle) [46]; C. bovis (beef cattle) [33]; C. canis (human) [32]; $C$. hominis (human, monkey) [32, 47]; $C$. meleagridis (human) [32]; $C$. muris (monkey) [47]; $C$. parvum (human) [32]; C. ryanae (cattle) [33]; C. scrofarum (pig) [49]; C. suis (pig, human, environmental sample) [32, 35, 38]; C. ubiquitum (human) [32]; Cryptosporidium avian genotype II (ostrich) [37]; Cryptosporidium bat genotype (bat) [45]; and Cryptosporidium pig genotype II (pig) [35] (Table 4). In Cambodia, Moore et al. detected many species of Cryptosporidium from symptomatic children in a hospital [32]. The species reported in their study were $C$. canis, $C$. hominis, $C$. meleagridis, $C$. parvum, and $C$. suis, all of which have zoonotic potential [31]. Cryptosporidium hominis and $C$. canis were detected in human samples collected at our study site, but $C$. suis was not. Cryptosporidium canis and $C$. suis were detected in animal samples collected at our study site, but $C$. hominis was not. All species detected in this study area could easily contaminate the environment and/or water and/or food through the excretion of stools that contain oocysts, and there is always a risk of a spillover of disease transmission to humans. Table 4 gave us the opportunity to estimate the potential for transmissions between animals and humans by different species of Cryptosporidium in Vietnam and surrounding countries. It should be noted that the majority of patients with HIV in the studies listed in Table 4 were infected with $C$. hominis and $C$. parvum. This is consistent with a previous study of children infected with HIV in Kenya [51, 52]. Although $C$. hominis is widely considered to be a human-specific Cryptosporidium species, it has increasingly been reported in animals from all over the world except Vietnam [53-55].

Cryptosporidium hominis is known to cause severe to moderate infections in humans [56]. More than ten subtypes of $C$. hominis have been identified, based on sequence analysis of the GP60 gene [30]. It has been reported that GP60 analysis has discriminatory power to determine transmission dynamics and source of infection [31].

In our study, only one subtype, leA12G3T3, was detected from all human diarrheal samples identified as having C. hominis based on COWP and/or SSU-rRNA gene analysis. This leA12G3T3 subtype has also been identified in various samples in other countries, such as stool specimens from individuals with HIV infection in Jamaica [57], water samples in Shanghai, China [58], stool specimens from Filipino immigrants in Qatar [59] and stool specimens from an immunocompromised patient in Slovakia [60]. Fortunately, this subtype has never been found to be responsible for an outbreak, and its infectivity or degree of virulence have yet to be reported. This is different from a notorious subtype, such as IbA10G2, which is widely distributed and was responsible for outbreaks in Europe, Australia, and the USA [31]. Following our investigation using GP60 subtyping for $C$. hominis, it became clear that one subtype (leA12G3T3) was dominant at our study site. We suspect that the transmission route might have been the same in all cases, occurring in neighboring households.

Our study has several limitations. First, the number of positive Cryptosporidium spp. cases was very small, comprising ten human diarrheal samples, two human non-diarrheal samples, and three animal stool samples. 
As the different sampling methods and timing for collecting these three kinds of samples could not be perfectly matched, it was very difficult to accomplish our ambitious goal to determine transmission routes using these samples.

Second, we are concerned that the PCR analyses used in our study might have underestimated the prevalence of Cryptosporidium spp. This could be due to one or more of the following reasons: DNA degradation [61], insufficient DNA [37], inhibition of PCR [62], and prolonged storage of the stool samples [63]. We were also concerned about cross-reactions with non-target organisms, such as algae, when we apply DFA [64], meaning we could not count the number of oocysts. False positive microscopy results were also not ruled out. Although our study objectives did not include estimating the exact prevalence or incident of cryptosporidiosis, such low detection of Cryptosporidium spp, was likely to miss several transmission routes and affect the objective of this study. In terms of storage of the samples, it was difficult to exactly match the conditions of storage time until DNA extraction for all samples collected over three years. As we followed the experimental process described in Fig. 1, the time until DNA extraction varied depending on the time to complete detection by DFA using microscopy, which was time consuming and laborious. In fact, all our stool samples were stored in the suitable condition for prolonged storage, according to the conditions noted by Jongwutiwes et al. [65]. In addition, each primer has a different detection rate when identifying Cryptosporidium spp. The primers targeting the COWP gene have higher detection rates than the primers targeting the SSU-rRNA region. The GP60 gene is usually used as a marker for the detection of $C$. parvum and $C$. hominis [28]. Therefore, we did not succeed using PCR to identify GP60 for the samples already detected as $C$. suis and $C$. canis by COWP and RRU-rRNA. Moreover, we did not detect any C. parvum-positive samples. Generally, in agricultural area, the risk of infection may be greater for larger livestock, such as buffalos and cattle, which are the main hosts of C. parvum. We suspected that zoonotic transmission was occurring from cattle and buffalos to humans. However, false negative PCR result was not ruled out, as mentioned above. In agricultural area of Vietnam, where there are many freeroaming livestock and no sewage systems, water is considered to be an important mechanism in the transmission of Cryptosporidium spp. If contamination of water from a particular population of animals is suspected, investigation of the water itself is needed to verify the risk of Cryptosporidium spp. to public health. In fact, contamination of water with Cryptosporidium spp. from pig farms at our study site might represent a growing problem unless sanitary conditions are improved.

Third, it is very difficult to determine the pathogenicity and virulence of Cryptosporidium. In terms of human cases at our study site, we suspect that $C$. hominis was more pathogenic than $C$. canis, even though we could not address this risk through our study design. Four cases of $C$. hominis, of the same subtype, were detected at the same time from human diarrheal samples. On the other hand, $C$. canis were detected sporadically from many kinds of samples, such as human diarrheal and non-diarrheal samples and dog stool samples, which were spread throughout our study site. The pattern of $C$. hominis and $C$. canis throughout our study were quite different and we suspect that Cryptosporidium spp. virulence or pathogenicity also differs. There have been reports of differences in clinical manifestations among Cryptosporidium species and subtypes [66-71]. In adults and children infected with HIV, for example, it has been suggested that $C$. hominis is mainly associated with diarrhea, nausea, vomiting, and malaise, whereas $C$. parvum, C. meleagridis, $C$. canis, and $C$. felis are associated with diarrhea only $[66,67]$. Another report, of the medium-to long-term impact of cryptosporidiosis, suggested that $C$. hominis infection is mainly associated with fatigue and abdominal pain greater than that seen with $C$. parvum infection $[69,70]$. In addition, different subtypes of $C$. hominis have been linked to variable 
clinical outcomes [71]. However, the etiology of diarrhea itself is very complicated, and we could not rule out pathogens except Cryptosporidium spp. as the cause of diarrhea. In fact, there was some additional information about other diarrheal pathogens from the human stool samples used in this study. These other pathogens were as follows: rotavirus, norovirus GI and norovirus GIl, Aeromonas spp., Campylobacter spp., Clostridium difficile, Enterotoxigenic Escherichia coli, enteroaggregative E coli, Salmonella spp., Shigella spp., Vibrio spp., Giardia spp., Entamoeba histolytica. The presence of these pathogens was investigated using the same samples already detected Cryptosporidium spp. in this study. Coincidentally, four samples which were positive for $C$. hominis were also positive for enteroaggregative $E$ coli (unpublished data). In cases of mixed infection with various diarrheal pathogens, it is very difficult to identify the etiology of diarrhea.

To control cryptosporidiosis, a "One Health approach" can be applied; this is a collaborative approach among public and veterinary health professionals. Although the distribution patterns of Cryptosporidium spp. vary from country to country and even from one region to another, we believe that even our small quantity of local molecular epidemiological data could contribute to improve the knowledge around the transmission of this parasite. In Vietnam, there have still been few studies focused on both public and veterinary health, as was the case with our study. Although our results are limited to one small area, our information could form part of a network of molecular-based surveillance systems. We believe that the accumulation of each local reports has a possibility to help reduce disease incidence in country level.

\section{Conclusions}

As cryptosporidiosis takes the largest toll on the health of vulnerable populations, such as patients who are immunodeficient and young children living in low-income settings, it is important to prevent infection by strictly minimizing the number of oocysts in the environment. Although the detection rate of Cryptosporidium spp. in our study was not high, it was certain that at least three species of Cryptosporidium were present. Particularly with $C$. canis, zoonotic transmission between dogs and humans was suspected. Cryptosporidium spp. is an environmentally ubiquitous protozoan parasite. Our study only used stool samples only, although Cryptosporidium spp. can also be found in water and environmental samples. As our study site is a typical agricultural area where there are many free-roaming livestock and no sewage systems, environmental surveillance would be helpful in avoiding outbreaks of cryptosporidiosis. Not only animal stools but also human stools could contaminate water with Cryptosporidium spp. at our study site, due to no sewage systems.

\section{Abbreviations}

COWP: oocyst wall protein

DFA: direct Immunofluorescence Assay

GP60: 60-kDa glycoprotein

MEGA: Molecular Evolutionary Genetic Analysis

MGL technique: formalin-Ether sedimentation (406 ${ }^{\text {th }}$ Medical General Laboratory; MGL) technique

SNP: single nucleotide polymorphisms

Page 10/40 


\section{Declarations}

\section{Ethics approval and consent to participate}

This study was approved by the Ethical Committee of the Graduate School of International Health and Development, Nagasaki University and the Institutional Review Board of NIHE in Vietnam. Written informed consent was obtained from participants, who were the head of the household for each household. A verbal consent statement was obtained from livestock owners prior to the collection of fecal samples from their private land.

As a major consideration, no patients who were immunocompromised or had AIDS/HIV were included in the study. Although the participants were notified and understood that the test results of their samples would not be available to assist in any treatment, they would be monitored for clinical manifestations of Cryptosporidium infection and other diarrheal symptoms trained health workers. The participants were advised to report any abnormal health status to the local physician in the Hien Khanh Commune Health Station, which was staffed with three physicians, one pharmacist, one midwife, and one nurse. If any manifestations of cryptosporidiosis occurred, all participants with diarrhea were treated at the community health center, according to Ministry of Health guidelines. In cases of severe diarrhea, participants were referred to the district or the provincial hospital for appropriate laboratory testing and treatment.

\section{Consent for publication}

Not applicable

\section{Availability of data and materials}

Not applicable

\section{Competing interests}

The authors declare that they have no competing interests.

\section{Funding}

This work was supported by the Program of Japan Initiative for Global Research Network on Infectious Diseases (J-GRID) (JP20wm0125006, JP19fm0108001) from the Ministry of Education, Culture, Sport, Science \& Technology in Japan, the Japan Agency for Medical Research and Development (AMED), and the Terumo life science foundation.

\section{Authors' contributions}

$\mathrm{HI}, \mathrm{TT}, \mathrm{AT}$ and TS conceived and designed this study. VDT, NHT and PDT planned the study in Vietnam. HI, AT, TS, NHT, PDT, PHQA, HTD and LNT collected the field data, and HI, TT, AT, TS, PHQA, HTD and LNT conducted the laboratory work. HI drafted the manuscript. All authors have read and approved the final manuscript. 


\section{Acknowledgments}

We wish to express our gratitude to the Hien Khanh Commune Health Center (Dr. Dao Anh Son), the Vu Ban Preventive Medical Center (Dr. Pham Van Hien), and the Nam Dinh province Preventive Medical Center (Dr. Do Duc Luu). We are deeply grateful to the community health volunteers and the residents of the Hien Khanh Commune who participated in this study. We wish to thank the National Institute of Hygiene and Epidemiology (NIHE) in Hanoi, the Vietnam Research Station of Nagasaki University and the University of the Ryukyus Center for Research Advancement and Collaboration for use of their facilities. Our heartfelt appreciation goes to Prof. Futoshi Hasebe for technical support, Mr. Takahiro Nakao, Mr. Kei Saito, Ms. Mayumi Nakano and Ms. Nobuko Sakakura for providing administrative support.

\section{References}

1. Pumipuntu N, Piratae S. Cryptosporidiosis: A zoonotic disease concern. Vet World. 2018;11:681-6.

2. Khan A, Shaik JS, Grigg ME. Genomics and molecular epidemiology of Cryptosporidium species. Acta Trop. 2018;184 October 2017:1-14. doi:10.1016/j.actatropica.2017.10.023.

3. Thompson RCA, Ash A. Molecular epidemiology of Giardia and Cryptosporidium infections - What's new? Infect Genet Evol. 2019;75 July.

4. Zahedi A, Ryan U. Cryptosporidium - An update with an emphasis on foodborne and waterborne transmission. Res Vet Sci. 2020;132 June:500-12.

5. Morris A, Robinson G, Swain MT, Chalmers RM. Direct Sequencing of Cryptosporidium in Stool Samples for Public Health. Front Public Heal. 2019;7 December.

6. Wang R jun, Li J qiang, Chen Y cai, Zhang L xian, Xiao L hua. Widespread occurrence of Cryptosporidium infections in patients with HIV/AIDS: Epidemiology, clinical feature, diagnosis, and therapy. Acta Trop. 2018;187 June:257-63. doi:10.1016/j.actatropica.2018.08.018.

7. Dumaine JE, Tandel J, Striepen B. Cryptosporidium parvum. Trends Parasitol. 2020;36:485-6. doi:10.1016/j.pt.2019.11.003.

8. Carrique-Mas JJ, Bryant JE. A review of foodborne bacterial and parasitic zoonoses in Vietnam. Ecohealth. 2013;10:465-89.

9. Vermeulen LC, Benders J, Medema G, Hofstra N. Global Cryptosporidium Loads from Livestock Manure. Environmental Science and Technology. 2017;51:8663-71.

10. Armon R, Gold D, Zuckerman U, Kurzbaum E. Environmental Aspects of Cryptosporidium. J Vet Med Res. 2016;3.

11. Bangalore M, Smith A, Veldkamp T. Exposure to Floods, Climate Change, and Poverty in Vietnam. Nat Hazards Earth Syst Sci Discuss. 2017;:1-28.

12. Lim YAL, Vythilingam I. Parasites and their vectors: A special focus on Southeast Asia. Springer Science \& Business Media; 2014.

13. Shrivastava AK, Kumar S, Smith WA, Sahu PS. Revisiting the global problem of cryptosporidiosis and recommendations. Trop Parasitol. 2017;7:8. https://www.ncbi.nlm.nih.gov/pmc/articles/PMC5369280/.

14. Uga S, Tanaka K, Iwamoto N. Evaluation and modification of the formalin-ether sedimentation technique. Trop Biomed. 2010;27:177-84. 
15. Yu JR, Lee SU, Park WY. Comparative sensitivity of PCR primer sets for detection of Cryptosporidium parvum. Korean J Parasitol. 2009;47:293-7.

16. Ryan U, Xiao L, Read C, Zhou L, Lal AA, Pavlasek I. Identification of novel Cryptosporidium genotypes from the Czech Republic. Appl Environ Microbiol. 2003;69:4302-7.

17. Xiao L, Escalante L, Yang C, Sulaiman I, Escalante AA, Montali RJ, et al. Phylogenetic analysis of Cryptosporidium parasites based on the small- subunit rRNA gene locus. Appl Environ Microbiol. 1999;65:1578-83.

18. Sulaiman IM, Hira PR, Zhou L, Al-Ali FM, Al-Shelahi FA, Shweiki HM, et al. Unique endemicity of cryptosporidiosis in children in Kuwait. J Clin Microbiol. 2005;43:2805-9.

19. Gatei W, Hart CA, Gilman RH, Das P, Cama V, Xiao L. Development of a multilocus sequence typing tool for Cryptosporidium hominis. Journal of Eukaryotic Microbiology. 2006;53 SUPPL. 1.

20. Abeywardena H, Jex AR, Nolan MJ, Haydon SR, Stevens MA, McAnulty RW, et al. Genetic characterisation of Cryptosporidium and Giardia from dairy calves: Discovery of species/genotypes consistent with those found in humans. Infect Genet Evol. 2012;12:1984-93. doi:10.1016/j.meegid.2012.08.004.

21. Essid R, Menotti J, Hanen C, Aoun K, Bouratbine A. Genetic diversity of Cryptosporidium isolates from human populations in an urban area of Northern Tunisia. Infect Genet Evol. 2018;58 January:237-42. doi:10.1016/j.meegid.2018.01.004.

22. Wesołowska M, Szostakowska B, Kicia M, Sak B, Kvac M, Knysz B. Cryptosporidium meleagridis infection: the first report in Poland of its occurrence in an HIV-positive woman. Ann Parasitol. 2016;62:239-41.

23. Panning M, Baumgarte S, Pfefferle S, Maier T, Martens A, Drosten C. Comparative analysis of rabies virus reverse transcription-PCR and virus isolation using samples from a patient infected with rabies virus. J Clin Microbiol. 2010;48:2960-2.

24. Rojas-Lopez L, Elwin K, Chalmers RM, Enemark HL, Beser J, Troell K. Development of a gp60-subtyping method for Cryptosporidium felis. Parasites and Vectors. 2020;13:1-8.

25. Liu A, Gong B, Liu X, Shen Y, Wu Y, Zhang W, et al. A retrospective epidemiological analysis of human Cryptosporidium infection in China during the past three decades (1987-2018). PLoS Negl Trop Dis. 2020;14:1-19. doi:10.1371/journal.pntd.0008146.

26. Ryan U, Zahedi A, Paparini A. Cryptosporidium in humans and animals-a one health approach to prophylaxis. Parasite Immunology. 2016;38:535-47.

27. Kimura M. A simple method for estimating evolutionary rates of base substitutions through comparative studies of nucleotide sequences. J Mol Evol. 1980;16:111-20.

28. Xiao L. Molecular epidemiology of cryptosporidiosis: An update. Exp Parasitol. 2010;124:80-9.

29. Gong C, Cao XF, Deng L, Li W, Huang XM, Lan JC, et al. Epidemiology of Cryptosporidium infection in cattle in China: A review. Parasite. 2017;24.

30. Xiao L, Feng Y. Molecular epidemiologic tools for waterborne pathogens Cryptosporidium spp. and Giardia duodenalis. Food Waterborne Parasitol. 2017;8:14-32.

31. Feng Y, Ryan UM, Xiao L. Genetic Diversity and Population Structure of Cryptosporidium. Trends Parasitol. 2018;34:997-1011. 
32. Moore CE, Elwin K, Phot N, Seng C, Mao S, Suy K, et al. Molecular Characterization of Cryptosporidium Species and Giardia duodenalis from Symptomatic Cambodian Children. PLoS Negl Trop Dis. 2016;10:113.

33. Nguyen ST, Fukuda Y, Tada C, Sato R, Duong B, Nguyen DT, et al. Molecular characterization of Cryptosporidium in native beef calves in central Vietnam. Parasitol Res. 2012;111:1817-20.

34. Gibson-Kueh S, Yang R, Thuy NTN, Jones JB, Nicholls PK, Ryan U. The molecular characterization of an Eimeria and Cryptosporidium detected in Asian seabass (Lates calcarifer) cultured in Vietnam. Vet Parasitol. 2011;181:91-6.

35. Nguyen ST, Fukuda Y, Tada C, Sato R, Huynh VV, Nguyen DT, et al. Molecular characterization of Cryptosporidium in pigs in central Vietnam. Parasitol Res. 2013;112:187-92.

36. Nguyen ST, Honma H, Geurden T, Ikarash M, Fukuda Y, Huynh VV, et al. Prevalence and risk factors associated with Cryptosporidium oocysts shedding in pigs in Central Vietnam. Res Vet Sci. 2012;93:84852.

37. Nguyen ST, Fukuda Y, Tada C, Huynh VV, Nguyen DT, Nakai Y. Prevalence and molecular characterization of Cryptosporidium in ostriches (Struthio camelus) on a farm in central Vietnam. Exp Parasitol. 2013;133:811. doi:10.1016/j.exppara.2012.10.010.

38. Nguyen TT, Traub R, Pham PD, Nguyen HV, Nguyen KC, Phung CD, et al. Prevalence and molecular characterization of Cryptosporidum spp. and Giardia spp. in environmental samples in Hanam province, Vietnam. Food Waterborne Parasitol. 2016;3:13-20. doi:10.1016/j.fawpar.2016.03.003.

39. Gatei W, Greensill J, Ashford RW, Cuevas LE, Parry CM, Cunliffe NA, et al. Molecular analysis of the 18S rRNA gene of Cryptosporidium parasites from patients with or without human immunodeficiency virus infections living in Kenya, Malawi, Brazil, the United Kingdom, and Vietnam. J Clin Microbiol. 2003;41:1458-62.

40. Ghaffari S, Kalantari N. Molecular analysis of 18S rRNA gene of Cryptosporidium parasites from patients living in Iran, Malawi, Nigeria and Vietnam. Int J Mol Cell Med. 2012;1:153-61. http://www.ncbi.nlm.nih.gov/pubmed/24551771\%0Ahttp://www.pubmedcentral.nih.gov/articlerender.fcgi? artid=PMC3920505.

41. Duong VT, Phat VV, Tuyen HT, Dung TTN, Trung PD, Minh P Van, et al. Evaluation of luminex xTAG gastrointestinal pathogen panel assay for detection of multiple diarrheal pathogens in fecal samples in Vietnam. J Clin Microbiol. 2016;54:1094-100.

42. Paboriboune P, Phoumindr N, Borel E, Sourinphoumy K, Phaxayaseng S, Luangkhot E, et al. Intestinal parasitic infections in HIV-infected patients, Lao People's Democratic Republic. PLoS One. 2014;9:1-8.

43. Chhin S, Harwell JI, Bell JD, Rozycki G, Ellman T, Barnett JM, et al. Etiology of chronic diarrhea in antiretroviral-naive patients with HIV infection admitted to Norodom Sihanouk Hospital, Phnom Penh, Cambodia. Clin Infect Dis. 2006;43:925-32.

44. Anh VT, Tram NT, Klank LT, Cam PD, Dalsgaard A. Faecal and protozoan parasite contamination of water spinach (Ipomoea aquatica) cultivated in urban wastewater in Phnom Penh, Cambodia. Trop Med Int Heal. 2007;12 SUPPL. 2:73-81.

45. Wang W, Cao L, He B, Li J, Hu T, Zhang F, et al. Molecular characterization of Cryptosporidium in bats from yunnan province, southwestern China. J Parasitol. 2013;99:1148-50. 
46. Wang R, Jian F, Zhang L, Ning C, Liu A, Zhao J, et al. Multilocus sequence subtyping and genetic structure of Cryptosporidium muris and Cryptosporidium andersoni. PLoS One. 2012;7.

47. Karim MR, Zhang S, Jian F, Li J, Zhou C, Zhang L, et al. Multilocus typing of Cryptosporidium spp. and Giardia duodenalis from non-human primates in China. Int J Parasitol. 2014;44:1039-47.

48. Ye J, Xiao L, Li J, Huang W, Amer SE, Guo Y, et al. Occurrence of human-pathogenic Enterocytozoon bieneusi, Giardia duodenalis and Cryptosporidium genotypes in laboratory macaques in Guangxi, China. Parasitol Int. 2014;63:132-7.

49. Zou Y, Ma JG, Yue DM, Zheng W Bin, Zhang XX, Zhao Q, et al. Prevalence and risk factors of Cryptosporidium infection in farmed pigs in Zhejiang, Guangdong, and Yunnan provinces, China. Trop Anim Health Prod. 2017;49:653-7.

50. Zun-Fu W, Zhi-Hua J, Bing-Xue Y, Dong-Sheng Z, Yuan L, Wen-Qian T. Preliminary study on infection status and gene types of Cryptosporidium among HIV/AIDS patients in Guangxi. Chinese $\mathrm{J}$ schistosomiasis Control. 2016;28:550-3.

51. Wanyiri JW, Kanyi H, Maina S, Wang DE, Steen A, Ngugi P, et al. Cryptosporidiosis in HIV/AIDS patients in Kenya: Clinical features, epidemiology, molecular characterization and antibody responses. Am J Trop Med Hyg. 2014;91:319-28.

52. Mbae C, Mulinge E, Waruru A, Ngugi B, Wainaina J, Kariuki S. Genetic Diversity of Cryptosporidium in Children in an Urban Informal Settlement of Nairobi, Kenya. PLoS One. 2015;10:1-18.

53. Jian F, Liu A, Wang R, Zhang S, Qi M, Zhao W, et al. Common occurrence of Cryptosporidium hominis in horses and donkeys. Infect Genet Evol. 2016;43:261-6.

54. Widmer G, Köster PC, Carmena D. Cryptosporidium hominis infections in non-human animal species: revisiting the concept of host specificity. Int J Parasitol. 2020;50:253-62.

55. Razakandrainibe R, Diawara EHI, Costa D, Le Goff L, Lemeteil D, Ballet JJ, et al. Common occurrence of Cryptosporidium hominis in asymptomatic and symptomatic calves in France. PLoS Negl Trop Dis. 2018;12:1-12.

56. Chalmers RM, Robinson G, Elwin K, Elson R. Analysis of the Cryptosporidium spp. and gp60 subtypes linked to human outbreaks of cryptosporidiosis in England and Wales, 2009 to 2017. Parasites and Vectors. 2019;12:1-13. doi:10.1186/s13071-019-3354-6.

57. Gatei W, Barrett D, Lindo JF, Eldemire-Shearer D, Cama V, Xiao L. Unique Cryptosporidium population in HIVinfected persons, Jamaica. Emerg Infect Dis. 2008;14:841.

58. Li N, Xiao L, Wang L, Zhao S, Zhao X, Duan L, et al. Molecular Surveillance of Cryptosporidium spp., Giardia duodenalis, and Enterocytozoon bieneusi by Genotyping and Subtyping Parasites in Wastewater. PLoS Negl Trop Dis. 2012;6.

59. Madi SB. Cryptosporidium spp., prevalence, molecular characterisation and socio-demographic risk factors among immigrants in Qatar. PLoS Negl Trop Dis. 2019;13:1-15.

60. Hatalová E, Valenčáková A, Luptáková L, Špalková M, Kalinová J, Halánová M, et al. The first report of animal genotypes of Cryptosporidium parvum in immunosuppressed and immunocompetent humans in Slovakia. Transbound Emerg Dis. 2019;66:243-9.

61. Couto MCM, Sudre AP, Lima MF, Bomfim TCB. Comparison of techniques for DNA extraction and agarose gel staining of DNA fragments using samples of Cryptosporidium. Vet Med (Praha). 2013;58:535-42. 
62. Schrader C, Schielke A, Ellerbroek L, Johne R. PCR inhibitors - occurrence, properties and removal. J Appl Microbiol. 2012;113:1014-26.

63. Lalonde LF, Gajadhar AA. Effect of storage media, temperature, and time on preservation of Cryptosporidium parvum oocysts for PCR analysis. Vet Parasitol. 2009;160:185-9.

64. Rodgers MR, Flanigan DJ, Jakubowski W. Identification of algae which interfere with the detection of Giardia cysts and Cryptosporidium oocysts and a method for alleviating this interference. Appl Environ Microbiol. 1995;61:3759-63.

65. Jongwutiwes S, Tiangtip R, Yentakarm S, Chantachum N. Simple method for long-term copro-preservation of Cryptosporidium oocysts for morphometric and molecular analysis. Trop Med Int Heal. 2002;7:257-64.

66. Bouzid M, Hunter PR, Chalmers RM, Tyler KM. Cryptosporidium pathogenicity and virulence. Clin Microbiol Rev. 2013;26:115-34.

67. Cama VA, Bern C, Roberts J, Cabrera L, Sterling CR, Ortega Y, et al. Cryptosporidium species and subtypes and clinical manifestations in children, Peru. Emerg Infect Dis. 2008;14:1567-74.

68. Cama VA, Ross JM, Crawford S, Kawai V, Chavez-Valdez R, Vargas D, et al. Differences in clinical manifestations among Cryptosporidium species and subtypes in HIV-infected persons. J Infect Dis. 2007;196:684-91.

69. Carter BL, Chalmers RM, Davies AP. Health sequelae of human cryptosporidiosis in industrialised countries: a systematic review. Parasit Vectors. 2020;13:443. doi:10.1186/s13071-020-04308-7.

70. Carter BL, Stiff RE, Elwin K, Hutchings HA, Mason BW, Davies AP, et al. Health sequelae of human cryptosporidiosis-a 12-month prospective follow-up study. Eur J Clin Microbiol Infect Dis. 2019;38:170917.

71. Cacciò SM, Chalmers RM. Human cryptosporidiosis in Europe. Clin Microbiol Infect. 2016;22:471-80.

\section{Tables}

Table 1. Primers used to detect and to sequence Cryptosporidium spp. 


\begin{tabular}{|c|c|c|c|c|c|c|c|}
\hline T arget gene & Step & $\begin{array}{c}\text { Primer } \\
\text { name }\end{array}$ & Nud eotice sequence ( $5^{\prime}$ to $3^{\prime}$ ) & Polarity & Product (bp) & Cycle condition & Reference \\
\hline \multirow{4}{*}{ COWP } & \multirow{2}{*}{ 1st } & Cry-15 & GT AGATAATGGAAGAGATTGTG & forward & \multirow{2}{*}{$550 \mathrm{bp}$} & \multirow{4}{*}{$\begin{array}{l}95^{\circ} \mathrm{C}, 5 \text { minutes, } 1 \text { cycle; } 94^{\circ} \mathrm{C}, 30 \\
\text { seconds, } 55^{\circ} \mathrm{C}, 30 \text { seconds, } 72^{\circ} \mathrm{C}, 1 \\
\text { minute } 45 \text { cycles; } 72^{\circ} \mathrm{C}, 7 \text { minutes, } 1 \\
\text { cycle }\end{array}$} & \multirow{4}{*}{ Yu et al. (2009 } \\
\hline & & Cry-9 & GGACTGAAATACAGGCATTATCTTG & reverse & & & \\
\hline & \multirow{2}{*}{$\begin{array}{l}\text { 2nd } \\
\text { PCR }\end{array}$} & Cry-15 & GT AGATAATGGAAGAGATTGTG & forward & \multirow{2}{*}{$311 \mathrm{bp}$} & & \\
\hline & & \begin{tabular}{|c|} 
cowpnest- \\
R2 \\
\end{tabular} & TCTGTATATCCWGGTGGGC & reverse & & & \\
\hline \multirow{4}{*}{ SSUrRNA } & \multirow{2}{*}{$\begin{array}{c}1 \mathrm{st} \\
\mathrm{PCR}\end{array}$} & $18 \mathrm{SiCF} 2$ & GACATATCATTCAAGTTTCTGACC & forward & \multirow{2}{*}{$758-763 \mathrm{bp}$} & \multirow{4}{*}{$\begin{array}{l}94^{\circ} \mathrm{C}, 5 \text { minutes, } 1 \text { cycle; } 94^{\circ} \mathrm{C}, 30 \\
\text { seconds, } 58^{\circ} \mathrm{C}, 30 \text { seconds, } 72^{\circ} \mathrm{C}, 20 \\
\text { seconds, } 45 \text { cycl es; } 72^{\circ} \mathrm{C}, 10 \text { minutes, } \\
1 \text { cycle }\end{array}$} & \multirow{4}{*}{$\begin{array}{l}\text { Ryan et al. } \\
(2003)\end{array}$} \\
\hline & & 18SiCR2 & CTGAAGGAGTAAGGAACAACC & reverse & & & \\
\hline & \multirow{2}{*}{$\begin{array}{l}\text { 2nd } \\
\text { PCR }\end{array}$} & $18 \mathrm{SiCF} 1$ & CCTATCAGCTTTAGACGGTAGG & forward & \multirow{2}{*}{$585-590 \mathrm{bp}$} & & \\
\hline & & 18SiCR 1 & TCTAAGAATTTCACCTCTGACTG & reverse & & & \\
\hline \multirow{4}{*}{ SSUrRNA } & \multirow{2}{*}{$\begin{array}{c}\text { 1st } \\
\text { PCR }\end{array}$} & $\begin{array}{c}\text { Cry-SSU- } \\
\text { F2 }\end{array}$ & TTCTAGAGCTAATACATGCG & forward & \multirow{2}{*}{$1325 \mathrm{bp}$} & \multirow{4}{*}{$\begin{array}{l}95^{\circ} \mathrm{C}, 5 \text { minutes, } 1 \text { cycle; } 95^{\circ} \mathrm{C}, 45 \\
\text { seconds, } 55^{\circ} \mathrm{C}, 45 \text { seconds, } 72^{\circ} \mathrm{C}, 1 \\
\text { mirite, } 45 \text { cycles; } 72^{\circ} \mathrm{C}, 7 \text { minutes, } 1 \\
\text { cycle }\end{array}$} & \multirow{4}{*}{$\begin{array}{c}\text { Xio et al. } \\
\text { (1999) }\end{array}$} \\
\hline & & $\begin{array}{c}\text { Cry-SSU- } \\
\text { R2 } \\
\end{array}$ & CCCATTTCCTTCGAAACAGGA & reverse & & & \\
\hline & \multirow{2}{*}{$\begin{array}{l}\text { 2nd } \\
\text { PCR }\end{array}$} & \begin{tabular}{|c|}
$\begin{array}{c}\text { Cry-SSU- } \\
\text { F3 }\end{array}$ \\
\end{tabular} & GGAAGGGTTGTATTTATTAGATAAAG & forward & \multirow{2}{*}{$825-830 \mathrm{bp}$} & & \\
\hline & & \begin{tabular}{|c|} 
Cry-SSU- \\
R3 \\
\end{tabular} & AAGGAGTAAGGAACAACCTCCA & reverse & & & \\
\hline \multirow{4}{*}{ GP60 } & \multirow{2}{*}{$\begin{array}{c}1 \mathrm{st} \\
\mathrm{PCR}\end{array}$} & AL3531 & ATAGTCTCCGCTGTATTC & forward & \multirow{2}{*}{$\approx 850 \mathrm{bp}$} & \multirow{2}{*}{$\begin{array}{l}94^{\circ} \mathrm{C}, 5 \text { minites, } 1 \text { cycle; } 94^{\circ} \mathrm{C}, 45 \\
\text { seconds, } 54^{\circ} \mathrm{C}, 45 \text { seconds, } 72^{\circ} \mathrm{C}, 90 \\
\text { seconds, } 45 \text { cycles; } 72^{\circ} \mathrm{C}, 10 \text { minutes, } \\
1 \text { cycle }\end{array}$} & \multirow{4}{*}{$\begin{array}{l}\text { Sulaimanet al. } \\
(2005) \\
\text { Gatei et al. } \\
(2006)\end{array}$} \\
\hline & & AL3533 & GAGATATATCTTGGTGCG & reverse & & & \\
\hline & \multirow{2}{*}{$\begin{array}{l}\text { 2nd } \\
\text { PCR }\end{array}$} & AL3532 & TCCGCTGTATTCTCAGCC & forward & \multirow{2}{*}{$\sim 550 \mathrm{bp}$} & \multirow{2}{*}{$\begin{array}{l}95^{\circ} \mathrm{C}, 5 \text { minutes, } 1 \text { cycle; } 94^{\circ} \mathrm{C}, 45 \\
\text { seconds, } 55^{\circ} \mathrm{C}, 45 \text { seconds, } 72^{\circ} \mathrm{C}, 90 \\
\text { seconds, } 45 \text { cycl es; } 72^{\circ} \mathrm{C}, 10 \text { minutes, } \\
1 \text { cycle }\end{array}$} & \\
\hline & & AL3533 & GAGATATATCTTGGTGCG & reverse & & & \\
\hline \multirow{4}{*}{ GP60 } & \multirow{2}{*}{$\begin{array}{c}1 \mathrm{st} \\
\mathrm{PCR}\end{array}$} & AL3531 & Same as above & forward & \multirow{2}{*}{$-850 \mathrm{bp}$} & \multirow{2}{*}{ Same as above } & \multirow{4}{*}{$\begin{array}{l}\text { Sulai man et al. } \\
\text { (2005) } \\
\text { Gatei et a. } \\
\text { (2006) }\end{array}$} \\
\hline & & AL3533 & Same as above & reverse & & & \\
\hline & \multirow{2}{*}{$\begin{array}{l}\text { 2nd } \\
\text { PCR }\end{array}$} & AL3532 & TCCGCTGTATTCTCAGCC & forward & & $\begin{array}{l}95^{\circ} \mathrm{C}, 5 \text { minutes, } 1 \text { cycle; } 94^{\circ} \mathrm{C}, 45 \\
\text { seconds, } 54^{\circ} \mathrm{C}, 45 \text { seconds, } 72^{\circ} \mathrm{C}, 1\end{array}$ & \\
\hline & & LX0029 & CGAACCACATTACAAATGAAGT & reverse & 0 & $\begin{array}{l}\text { minutes, } 45 \text { cycles; } 72^{\circ} \mathrm{C}, 10 \text { minutes, } \\
1 \text { cycle }\end{array}$ & \\
\hline
\end{tabular}

Table 2. Genotype characterization of Cryptosporidium isolates from stool samples 


\begin{tabular}{|c|c|c|c|c|c|c|c|}
\hline \multirow{2}{*}{ Sample ID } & \multirow{2}{*}{ ID } & \multirow{2}{*}{ Sample } & \multirow{2}{*}{$\begin{array}{c}\text { Age } \\
\text { (years old) }\end{array}$} & \multirow{2}{*}{ Sampling period } & \multicolumn{3}{|c|}{ Genotype } \\
\hline & & & & & COWP & $S S U-r R N A$ & GP6O \\
\hline & $589 \_7$ & $\begin{array}{c}\text { Human non- } \\
\text { diarrheal }\end{array}$ & 2 & 28 October, 2014 & C. canis & C. canis & \\
\hline & $1766 \_4$ & $\begin{array}{l}\text { Human non- } \\
\text { diarrheal }\end{array}$ & 2 & 19 September, 2014 & C. canis & C. canis & \\
\hline Ani_74 & & Piglets $^{1}$ & young $^{1}$ & 4 September, 2015 & C. suis & C. suis & \\
\hline Ani_97 & & Sow \& Piglet ${ }^{2}$ & adult+young $^{2}$ & 22 September, 2015 & C. suis & C. suis & \\
\hline Ani_140 & & $\operatorname{Dog}^{3}$ & adult $^{3}$ & September, 2015 & C. canis & canis & \\
\hline CDS_263 & 1140_6 & Human diarrheal & 2 & 26 Aptil, 2015 & C. canis & & \\
\hline CDS_449 & $551 \_5$ & Human diarrheal & 26 & 8 July, 2015 & C.canis & & \\
\hline CDS_1147 & $1032 \_3$ & Human diarrheal & 7 & 19 March, 2016 & C. canis & & \\
\hline CDS_1197 & $242 \_6$ & Human diarrheal & 1 & 17 April, 2016 & C. canis & & \\
\hline CDS_1216 & $1731 \_8$ & Human diarrheal & 6 & 21 April, 2016 & C. canis & & \\
\hline CDS_1284 & $122 \_6$ & Human diarrheal & 5 & 11 May, 2016 & C. canis & & \\
\hline CDS_1788 & $400 \_2$ & Human diarrheal & 70 & & C. hominis & C. hominis & C. hominis ${ }^{4}$ \\
\hline CDS_1789 & $400 \_4$ & Human diarrheal & 37 & & C. hominis & C. hominis & C. hominis ${ }^{4}$ \\
\hline CDS_1790 & $422 \_3$ & Human diarrheal & 15 & & C. hominis & C. hominis & C. hominis ${ }^{4}$ \\
\hline CDS 1791 & 4224 & Human diarrheal & 11 & & C. hominis & & C. hominis ${ }^{4}$ \\
\hline
\end{tabular}

${ }^{1}$ This was mixed stool sample collected from 12 piglets. ${ }^{2}$ This was mixed stool sample collected from 1 sow and 1 piglet.

${ }^{3}$ This was collected from one adult dog kept in the household. ${ }^{4}$ Subtype leA12G3T3 was identified.

Table 3. Diversity and frequency of all sequence results including single-nucleotide polymorphisms of $C$. canis isolate at the COWP gene 


\begin{tabular}{|c|c|c|c|c|c|c|c|c|}
\hline \multirow{3}{*}{ Sample ID } & \multirow{3}{*}{ Sample } & \multirow{3}{*}{$\begin{array}{c}\text { GenBank } \\
\text { accession number }\end{array}$} & \multirow{3}{*}{$\begin{array}{l}\text { Product } \\
\text { size (bp) }\end{array}$} & \multirow{3}{*}{ Stretch } & \multicolumn{4}{|c|}{$\begin{array}{l}\text { Nucleotide at position of } \\
\text { reference sequence } \\
\text { AF266274.1 }\end{array}$} \\
\hline & & & & & 213 & 320 & 352 & 372 \\
\hline & & & & & A & $\mathrm{C}$ & A & $\mathrm{T}$ \\
\hline $589{ }_{-} 7$ & Human non-dirrheal & LC503972* & 506 & $17-522$ & & & & $\mathrm{C}$ \\
\hline $1766 \_4$ & Human non-dirrheal & LC503972* & 506 & $17-522$ & & & & $\mathrm{C}$ \\
\hline Ani_140 & Dog & - & 354 & $17-370$ & & & & \\
\hline CDS_263 & Human diarrheal & LC503969* & 354 & $17-370$ & & & G & \\
\hline CDS_449 & Human diarrheal & LC503970* & 354 & $17-370$ & & $\mathrm{~T}$ & & \\
\hline CDS_1147 & Human diarrheal & LC503971* & 506 & $17-522$ & G & & & $\mathrm{C}$ \\
\hline CDS_1197 & Human diarrheal & LC503972* & 506 & $17-522$ & & & & $\mathrm{C}$ \\
\hline CDS_1216 & Human diarrheal & LC503972* & 506 & $17-522$ & & & & $\mathrm{C}$ \\
\hline CDS_1284 & Human diarrheal & LC503972* & 506 & $17-522$ & & & & $\mathrm{C}$ \\
\hline
\end{tabular}

* The novel sequences without heterogeneous positions were newly submitted to GenBank

Table 4. Studies of Cryptosporidium infection in Vietnam and surrounding countries or area (Laos, Cambodia, southern provinces of China). 


\begin{tabular}{|c|c|c|c|c|c|c|c|c|}
\hline Country & Studyarea & Population/Source & $\begin{array}{l}\text { Method for Prevalence } \\
\text { calculation }\end{array}$ & Prevalence $(\%)$ & $\begin{array}{l}\text { Genes for } \\
\text { species } \\
\text { dentification }\end{array}$ & Species & $\begin{array}{l}\text { Gp60 subtype } \\
\text { (C.hominis } \\
\text { and } \\
\text { C.parvum) }\end{array}$ & $\begin{array}{l}\text { Reference (published } \\
\text { year) } \\
\text { [Sampling date] }\end{array}$ \\
\hline $\begin{array}{l}\text { Vietnam } \\
\text { (central) }\end{array}$ & $\begin{array}{l}\text { Dac Lac province (beef } \\
\text { farms) }\end{array}$ & $\begin{array}{l}\text { mative beef calves } 2-6 \\
\text { months old }\end{array}$ & $\begin{array}{l}\text { modified Ziehl-Neelsen } \\
(\mathrm{mZN}) \text { staining method }\end{array}$ & $\begin{array}{l}\text { The overall prevalence: } \\
18.9 \%(44 / 232) \text {, } \\
\text { herd level : } 50 \%(20 / 40)\end{array}$ & $18 \mathrm{~S}$ rRNA & $\begin{array}{l}\text { C. rycnae, } \\
\text { C. bovis }\end{array}$ & $\mathrm{NA}$ & $\begin{array}{l}\text { Nguyen et al. (2012a) } \\
\text { [January and April } \\
\text { 2011] }\end{array}$ \\
\hline $\begin{array}{l}\text { Vietnam } \\
\text { (south) }\end{array}$ & $\begin{array}{l}\text { Ca Mau province } \\
\text { (nursery) }\end{array}$ & $\begin{array}{l}\text { Asian seabass (Lates } \\
\text { calcarifer) : formalin fix ed } \\
\text { Vietnamese L.calcarifer } \\
\text { issue samples }\end{array}$ & $\begin{array}{l}\text { Partial 18S rRNA gene } \\
\text { sequences }\end{array}$ & $20 \%(2 / 10)$ & $18 \mathrm{~S}$ rRNA & $\begin{array}{l}\text { C. parvum-like, } \\
\text { C. hominis-like }\end{array}$ & $\mathrm{NA}$ & $\begin{array}{l}\text { Gibson-Kueh et al. } \\
2011) \\
{[2008]}\end{array}$ \\
\hline $\begin{array}{l}\text { Nietnam } \\
\text { (central) }\end{array}$ & $\begin{array}{l}\text { Pac Lac province (pig } \\
\text { farm) }\end{array}$ & pig & $\begin{array}{l}\text { modified Ziehl-Neelsen } \\
(\mathrm{mZN}) \text { staining method }\end{array}$ & $14.5 \%(28 / 193)$ & $\begin{array}{l}\text { 18S rRNA, } \\
\text { HSP70 }\end{array}$ & $\begin{array}{l}\text { C. slis, } \\
\text { Cryptosporidinon } \\
\text { pig genotype II }\end{array}$ & $\mathrm{NA}$ & $\begin{array}{l}\text { Nguyen et al. (2013a) } \\
\text { [October 2009 to } \\
\text { January 2010] }\end{array}$ \\
\hline $\begin{array}{l}\text { Vietnam } \\
\text { (central) }\end{array}$ & $\begin{array}{l}\text { BinhDinh province, } \\
\text { KhanhHoa province and } \\
\text { PacLac province (Fam) }\end{array}$ & pig & $\begin{array}{l}\text { modified Ziehl-Neelsen } \\
(\mathrm{mZN}) \text { staining method }\end{array}$ & $18.1 \%(134 / 740)$ & $\mathrm{NA}$ & C. parvim* & $\mathrm{NA}$ & $\begin{array}{l}\text { Nguyen et al. (2012b) } \\
\text { [February and } \\
\text { December 2009] }\end{array}$ \\
\hline $\begin{array}{l}\text { Vietnam } \\
\text { central) }\end{array}$ & $\begin{array}{l}\text { Khanh Hoa province } \\
\text { (ostrich farm) }\end{array}$ & ostrich & $\begin{array}{l}\text { modified Ziehl-Neelsen } \\
(\mathrm{mZN}) \text { staining method }\end{array}$ & $23.7 \%(110 / 464)$ & $\begin{array}{l}\text { I8S rRNA, } \\
\text { ASP70, } \\
\text { actin }\end{array}$ & $\begin{array}{l}\text { Cryptosporidiuon } \\
\text { avian genotype II }\end{array}$ & $\mathrm{NA}$ & $\begin{array}{l}\text { Nguyen et al. (2013b) } \\
\text { [January to March } \\
\text { 2011] }\end{array}$ \\
\hline $\begin{array}{l}\text { Vietnam } \\
\text { (north) }\end{array}$ & Hanam province & $\begin{array}{l}134 \text { enviommantal } \\
\text { samples }\end{array}$ & $\begin{array}{l}\text { All samples positive by } \\
\text { Immunofluorescence Assay } \\
\text { IFA) microscopywere } \\
\text { screened for the presence of } \\
\text { Cryptosporidium by PCR. }\end{array}$ & $\begin{array}{l}\text { Total } 35.0 \%(47 / 134) ; \\
\text { Nhue river water } \\
41.6 \%(10 / 24) \text {, Sewage } \\
66.7 \%(16 / 24) \text {, Fishpond } \\
\text { water } 25.0 \%(8 / 32) \text {, Canal } \\
\text { water } 39.1 \%(9 / 23) \\
\text { Vegetables } 15.3 \%(4 / 26) \text {, } \\
\text { Composed water } 0 \%(0 / 5) \\
\end{array}$ & $18 \mathrm{~S}$ rRNA & C. suis & $\mathrm{NA}$ & $\begin{array}{l}\text { Nguyne et al. (2016) } \\
\text { [February 2009 and } \\
\text { July 2009] }\end{array}$ \\
\hline Vietnam & NA & HIV-infected patients & $\mathrm{NA}$ & $\mathrm{NA}$ & $18 \mathrm{~S}$ rRNA & C. parvim human & NA & $\begin{array}{l}\text { Gatei et al. (2003) } \\
\text { NA] }\end{array}$ \\
\hline Vietnam & $\mathrm{NA}$ & $\begin{array}{l}2 \text { human (children, } \\
\text { diarrheic) samples }\end{array}$ & $\mathrm{NA}$ & $\mathrm{NA}$ & $18 \mathrm{~S}$ rRNA & C. hominis & $\mathrm{NA}$ & $\begin{array}{l}\text { Ghaffari et al.(2012) } \\
\text { [NA] }\end{array}$ \\
\hline $\begin{array}{l}\text { Vietnam } \\
\text { (south) }\end{array}$ & $\begin{array}{l}\text { Ho Chi Mrnh City, Dong } \\
\text { Thap province, Dak Lak } \\
\text { province, Khanh Hoa } \\
\text { province, Thua Thien } \\
\text { Hue province }\end{array}$ & $\begin{array}{l}\text { Stool samples collected } \\
\text { from people admitted to } \\
\text { the hospital for diarrhe al } \\
\text { disease throughout } \\
\text { Vietnam. }\end{array}$ & $\begin{array}{l}\text { The Luminex xTAG } \\
\text { gastrointestinal pathogen } \\
\text { panel assay (GPP) (Luminex } \\
\text { Mblecular Diagnostics, } \\
\text { Austin, TX, USA) }\end{array}$ & $17 \%(83 / 479)$ & $\mathrm{NA}$ & NA & $\mathrm{NA}$ & $\begin{array}{l}\text { Duong et al. (2016) } \\
\text { [during } 2009 \text { to 2014] }\end{array}$ \\
\hline aos & $\begin{array}{l}\text { Vientiane (Vientiane } \\
\text { Capital) and Savannakhet } \\
\text { province (Southern part } \\
\text { pf Laos) }\end{array}$ & $\begin{array}{l}\text { HIV-infected patients: two } \\
\text { public hospitals (Vientian } \\
\text { and Savannalhet) }\end{array}$ & $\begin{array}{l}\text { modified Ziehl-Neelsen } \\
(\mathrm{mZN}) \text { staining method }\end{array}$ & $\begin{array}{l}6.6 \%(9 / 137) \text { (=Vientiane: } \\
10.5 \%(7 / 67), \\
\text { Savannakhet: } 2.9 \%(2 / 70))\end{array}$ & NA & $\mathrm{NA}$ & $\mathrm{NA}$ & $\begin{array}{l}\text { Paboriboune et al. } \\
\text { (2014) } \\
\text { [October 2009 to } \\
\text { September 2010] }\end{array}$ \\
\hline Cambodia & $\begin{array}{l}\text { Phnom Penh (Cambodian } \\
\text { Capital) }\end{array}$ & $\begin{array}{l}\text { nfIV-infected patients } \\
\text { (adults): hospital }\end{array}$ & $\begin{array}{l}\text { modified Ziehl-Neelsen } \\
(\mathrm{mZN}) \text { staining method }\end{array}$ & $\begin{array}{l}\text { Patients with chronic } \\
\text { diarrhea: } 40 \%(16 / 40) \text {, } \\
\text { Patients wi thout chronic } \\
\text { tiatrhea: } 50 \%(20 / 40)\end{array}$ & $18 \mathrm{~S}$ rRNA & $\begin{array}{l}\text { C. hominis } \\
\text { C. parvum }\end{array}$ & $\mathrm{NA}$ & $\begin{array}{l}\text { Chhin et al. (2006) } \\
\text { [From January 2001 } \\
\text { to April 2001] }\end{array}$ \\
\hline
\end{tabular}

*The size and morphology of all oocysts were similar to those described for $C$. parvum and related Cryptosporidium species and genotypes.

Table 4. Studies of Cryptosporidium infection in Vietnam and surrounding countries or area. (continued) 


\begin{tabular}{|c|c|c|c|c|c|c|c|c|}
\hline Contry & Study area & Population/Source & $\begin{array}{l}\text { Method for } \\
\text { Prevalence } \\
\text { calculation }\end{array}$ & Prevalence (\%) & $\begin{array}{l}\text { Genes for species } \\
\text { identification }\end{array}$ & Species & $\begin{array}{l}\text { Gp60 subtype } \\
(\text { C. hominis and } \\
\text { C.panvum })\end{array}$ & $\begin{array}{l}\text { Reference (published } \\
\text { year) } \\
\text { [Sampling date] }\end{array}$ \\
\hline $\begin{array}{l}\text { Cambodia (North- } \\
\text { Wstem) }\end{array}$ & Siem Reap & $\begin{array}{l}\text { Children attending } \\
\text { he out patient clinic } \\
\text { pr admitted to } \\
\text { hospital }\end{array}$ & $\begin{array}{l}\text { Ziehl-Neelsen } \\
(\mathrm{mZN}) \text { s taining } \\
\text { method, } \\
18 \mathrm{r} \text { RNA real time } \\
\text { PCR }\end{array}$ & \begin{tabular}{|l|} 
Cnptosporidium \\
pocysts detected \\
psing microscopy: \\
$2.2 \%$ (11/498) \\
jetected with \\
molecular tes ts: $7.7 \%$ \\
$(38 / 498)$
\end{tabular} & $18 \mathrm{~S}$ rNA, Gp60 & $\begin{array}{l}\text { C. hominis, } \\
\text { C. meleagridis, } \\
\text { C. parvum, C. canis, } \\
\text { C. suis, } \\
\text { C. ubiquitum }\end{array}$ & $\begin{array}{l}\text { C. hominis sybtype } \\
\text { TaAl6R } 6 \text {, } \\
\text { C. parvum subtype } \\
\text { IeA } 7 \mathrm{G} 1\end{array}$ & $\begin{array}{l}\text { Moore et al. (2016) } \\
\text { between 3rd April } \\
2012 \text { and } 29 \text { th June } \\
2012 \text { ] }\end{array}$ \\
\hline Cambodia & $\begin{array}{l}\text { Boeng Cheung Ek } \\
\text { ake (located } 5-7 \mathrm{~km} \\
\text { pouth of the capital } \\
\text { Phnom Penh) }\end{array}$ & $\begin{array}{l}\text { water spinach and } \\
\text { ake water }\end{array}$ & $\begin{array}{l}\text { fluorescence } \\
\text { microscope using } \\
\text { fluorescent } \\
\text { monoclonal } \\
\text { antibodies }\end{array}$ & $\begin{array}{l}\text { Cryptosporidium } \\
\text { oocys ts from w ater } \\
\text { spinach samples: } \\
17 \%(6 / 36)\end{array}$ & NA & $\mathrm{NA}$ & NA & $\begin{array}{l}\text { Anh et al. (2007) } \\
\text { from July } 2004 \text { to } \\
\text { May 2005] }\end{array}$ \\
\hline China (south) & Yunnan Province & A total of 247 bats & $\begin{array}{l}\text { nested PCR based on } \\
\text { the } 18 S \text { rRNA gene }\end{array}$ & $7.7 \%(19 / 247)$ & $18 S$ rRNA & $\begin{array}{l}\text { Cryptosporidium bat } \\
\text { Eenotype I } \\
\text { Cryptosporidium bat } \\
\text { Eenotype II }\end{array}$ & NA & $\begin{array}{l}\text { Wang et a1. (2013) } \\
\text { [During 2010- 2011] }\end{array}$ \\
\hline China (south) & Guangxi & Pairy cattle & NA & NA & $18 \mathrm{~S}$ RNA & C. anders oni & NA & $\begin{array}{l}\text { Wang et al. (2012) } \\
\text { [NA] }\end{array}$ \\
\hline China (south) & $\begin{array}{l}\text { three monkey farms } \\
\text { and one nature } \\
\text { reserve in G uangxi } \\
\text { Zhu ang Avtonomous } \\
\text { Region, one zoo and } \\
\text { one research facility } \\
\text { in Yunnan Province }\end{array}$ & $\begin{array}{l}\text { Fresh faecal } \\
\text { pecimens from non- } \\
\text { human primates: in } \\
\text { Gvangxi Zhuang } \\
\text { Avtonomovs Region } \\
(\mathrm{n}=1079) \text {, in Yunnan } \\
\text { Province }(\mathrm{n}=144) \\
\end{array}$ & $\begin{array}{l}\text { nested PCR based on } \\
\text { the } 18 \mathrm{~S} \text { RNA gene }\end{array}$ & $\begin{array}{l}\text { Guangxi: } 1 \% \\
(11 / 1079) \text { Yunnan: } \\
\rho \%(0 / 144)\end{array}$ & $\begin{array}{l}18 S \text { rRNA, HS P70, } \\
\text { GP60 }\end{array}$ & C. hominis, C.moris & $\begin{array}{l}\text { C. hominis subtype } \\
\text { IbA } 12 \text { G } 3 \text {, IA } 17\end{array}$ & $\begin{array}{l}\text { Karim et a1. (2014) } \\
{[2006 \text { and 2013] }}\end{array}$ \\
\hline China (south) & $\begin{array}{l}\text { Guangxi } \\
\text { (commercial animal } \\
\text { facility) }\end{array}$ & $\begin{array}{l}205 \text { crab-eating } \\
\text { macaques (Macaca } \\
\text { fascicud aris) } \rightarrow \text { Group } \\
1 \text { (young monkeys in } \\
\text { ingle cages, } n=168 \text { ), } \\
\text { Group } 2 \text { (young } \\
\text { monkeys in group } \\
\text { kages, } n=18 \text { ), Group } \\
3 \text { (adu1ts in group } \\
\text { kases, } n=19 \text { ) } \\
\end{array}$ & $\begin{array}{l}\text { PCR-RFLP (18S } \\
\text { RNA) }\end{array}$ & $\begin{array}{l}\text { Group 1: } 0 \% \\
(0 / 168), \text { Group 2: } 0 \% \\
(0 / 18), 5.3 \%(1 / 19)\end{array}$ & $18 \mathrm{~S}$ rRNA, Gp60 & C. hominis & $\begin{array}{l}\text { C. hominis subtype } \\
\text { Id. } 14\end{array}$ & $\begin{array}{l}\text { Ye et al. (2014) } \\
\text { in December 2011] }\end{array}$ \\
\hline China (south) & $\begin{array}{l}\text { Yunnan province } \\
\text { (Pig farms) }\end{array}$ & pig $(n=200)$ & nes ted PCR & $23 \%(46 / 200)$ & $18 \mathrm{~S}$ rRNA & C. scrofarim & NA & $\begin{array}{l}\text { Zou et al. (2017) } \\
\text { [2016] }\end{array}$ \\
\hline China (south) & $\begin{array}{l}\text { Guangxi Zhuang } \\
\text { Autonomous Region }\end{array}$ & $\begin{array}{l}285 \mathrm{HIV} / \mathrm{AID} \text { cases } \\
150 \mathrm{HIV} \text { negative } \\
\text { persons }\end{array}$ & $\begin{array}{l}\text { modified acid-fast } \\
\text { staining and nested } \\
\text { PCR based on } 18 S \\
\text { RNA }\end{array}$ & $\begin{array}{l}\text { HIV/AIDS patients: } \\
0.7 \%(2 / 285), \\
\text { HIV negative } \\
\text { persons: } 0 \%(0 / 150)\end{array}$ & $18 \mathrm{~s}$ rRA & $\begin{array}{l}\text { C. anders oni, } \\
\text { C. hominis }\end{array}$ & NA & $\begin{array}{l}\text { Zon-Fu et al. (2016) } \\
\text { [2016] }\end{array}$ \\
\hline
\end{tabular}

\section{NA: Not applicable}

\section{Figures}




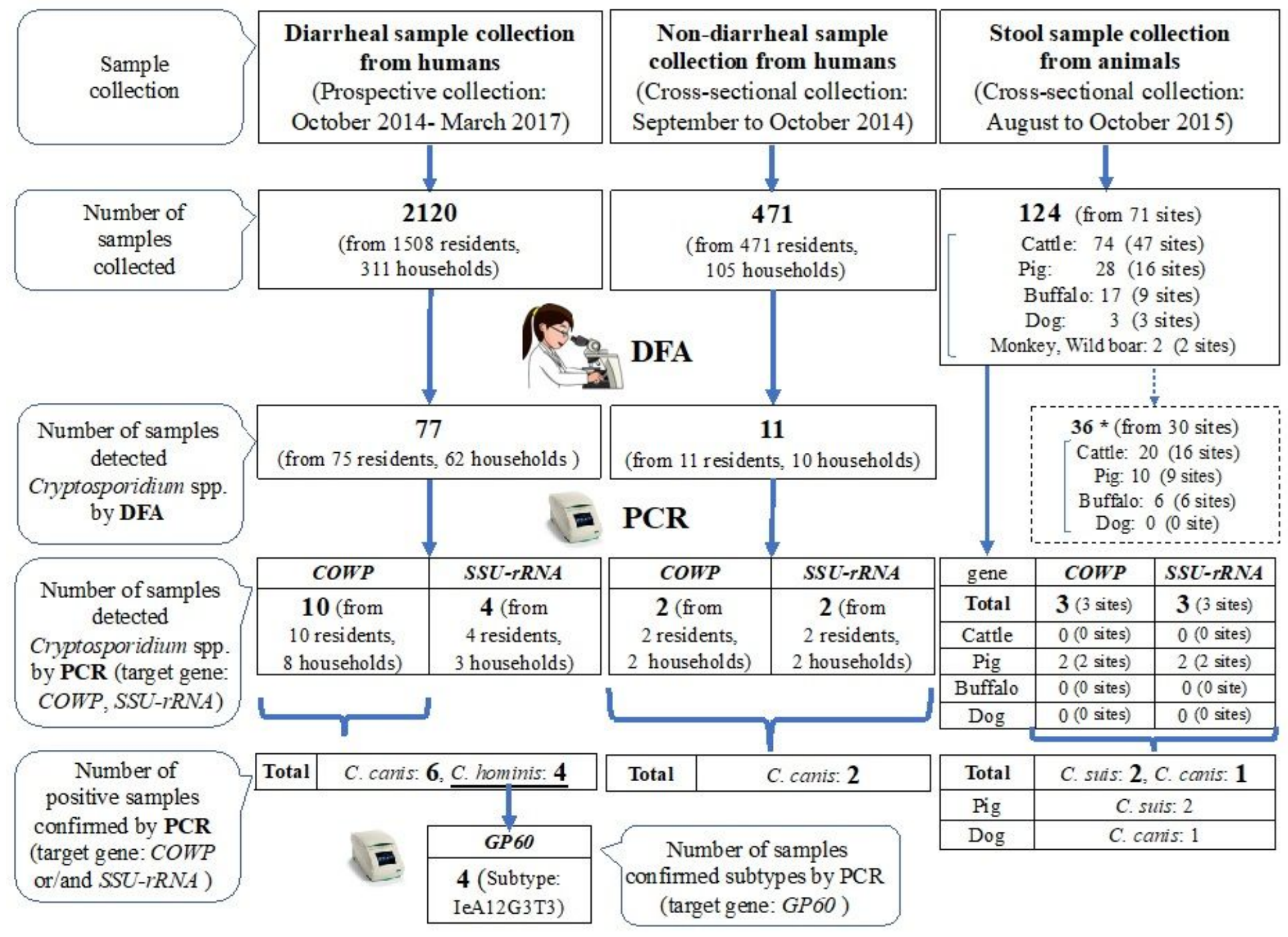

Figure 1

Algorithm for diagnosis and results of molecular genotyping of Cryptosporidium spp. 


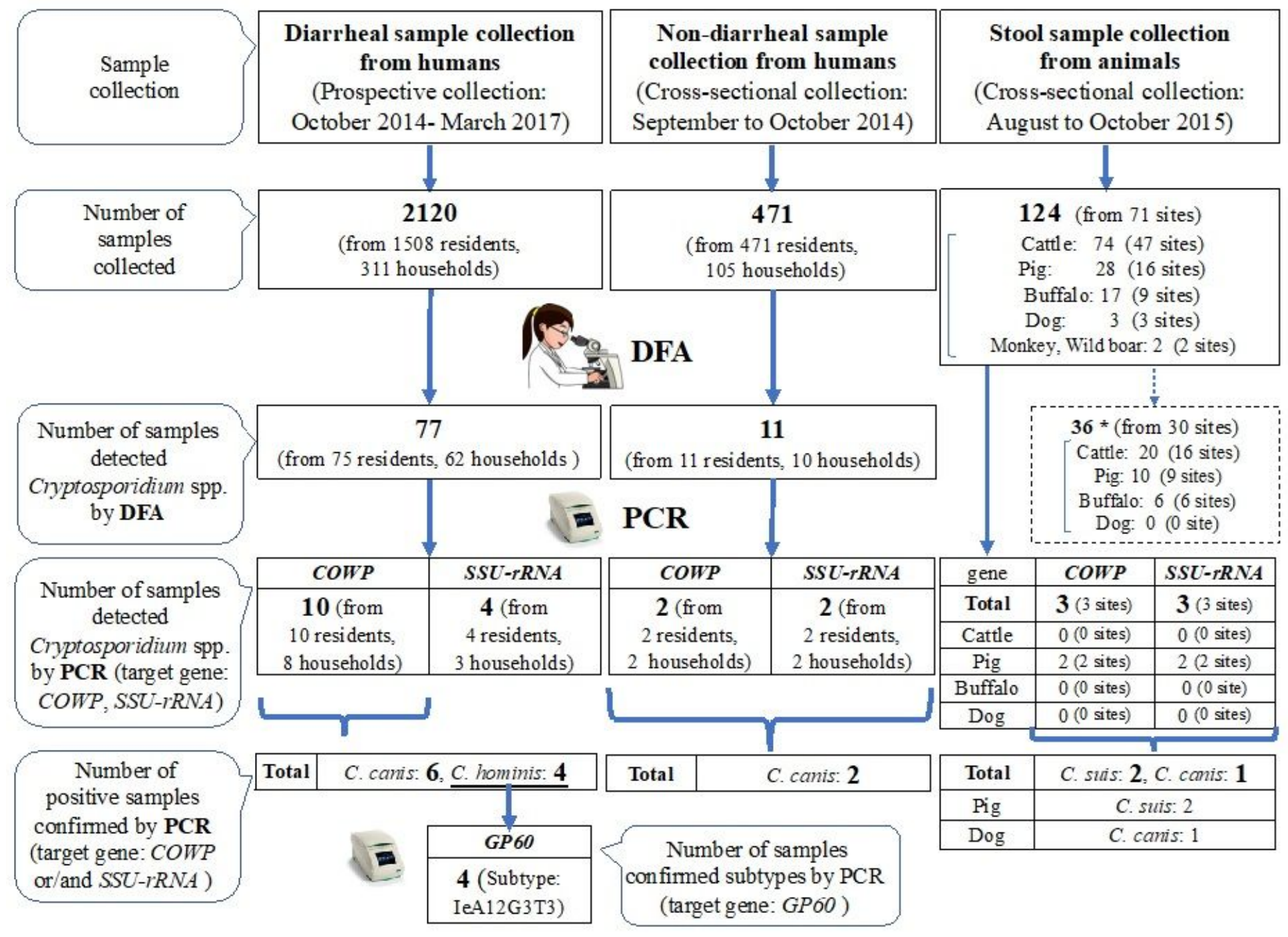

\section{Figure 1}

Algorithm for diagnosis and results of molecular genotyping of Cryptosporidium spp. 


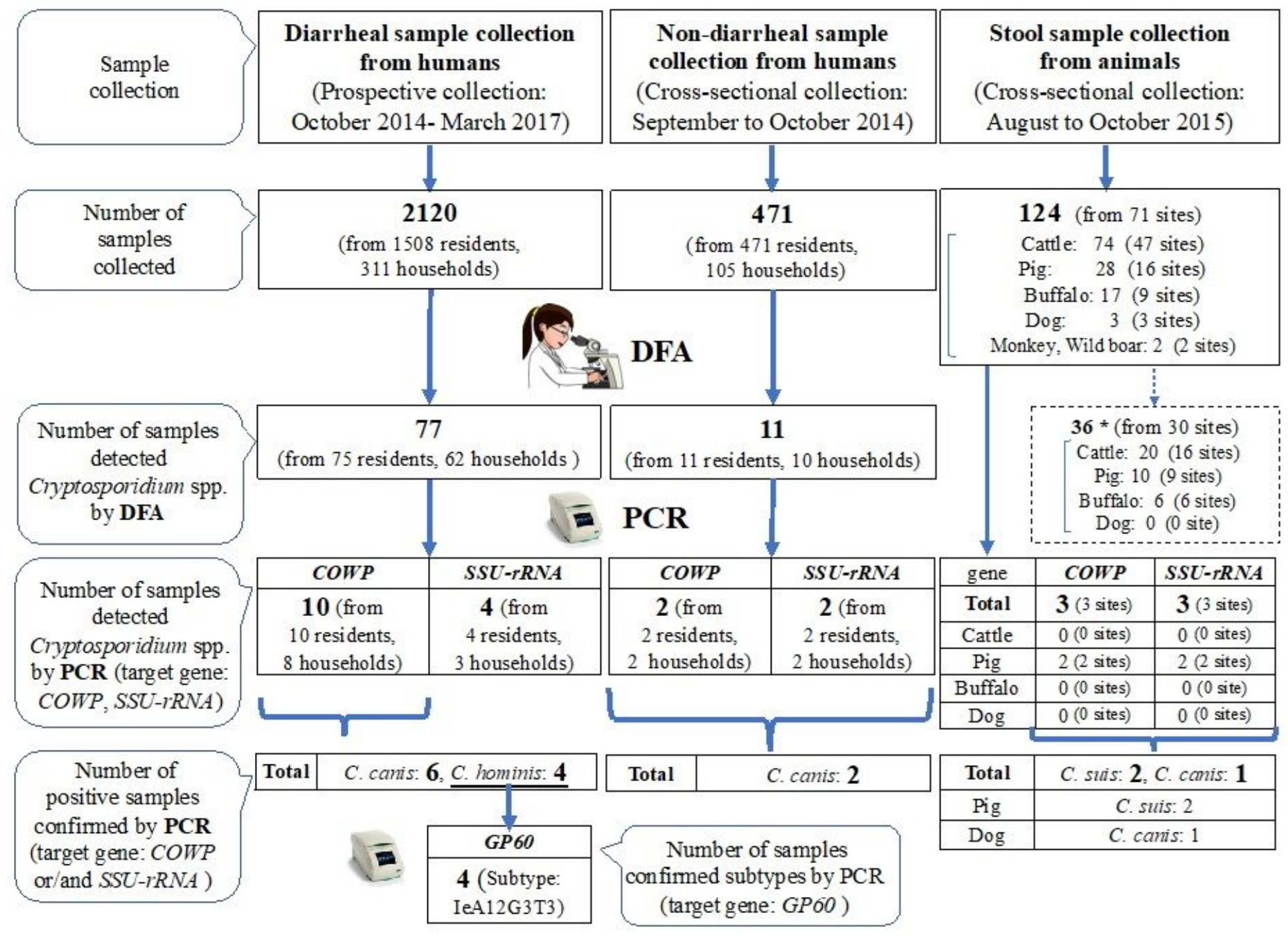

Figure 1

Algorithm for diagnosis and results of molecular genotyping of Cryptosporidium spp. 


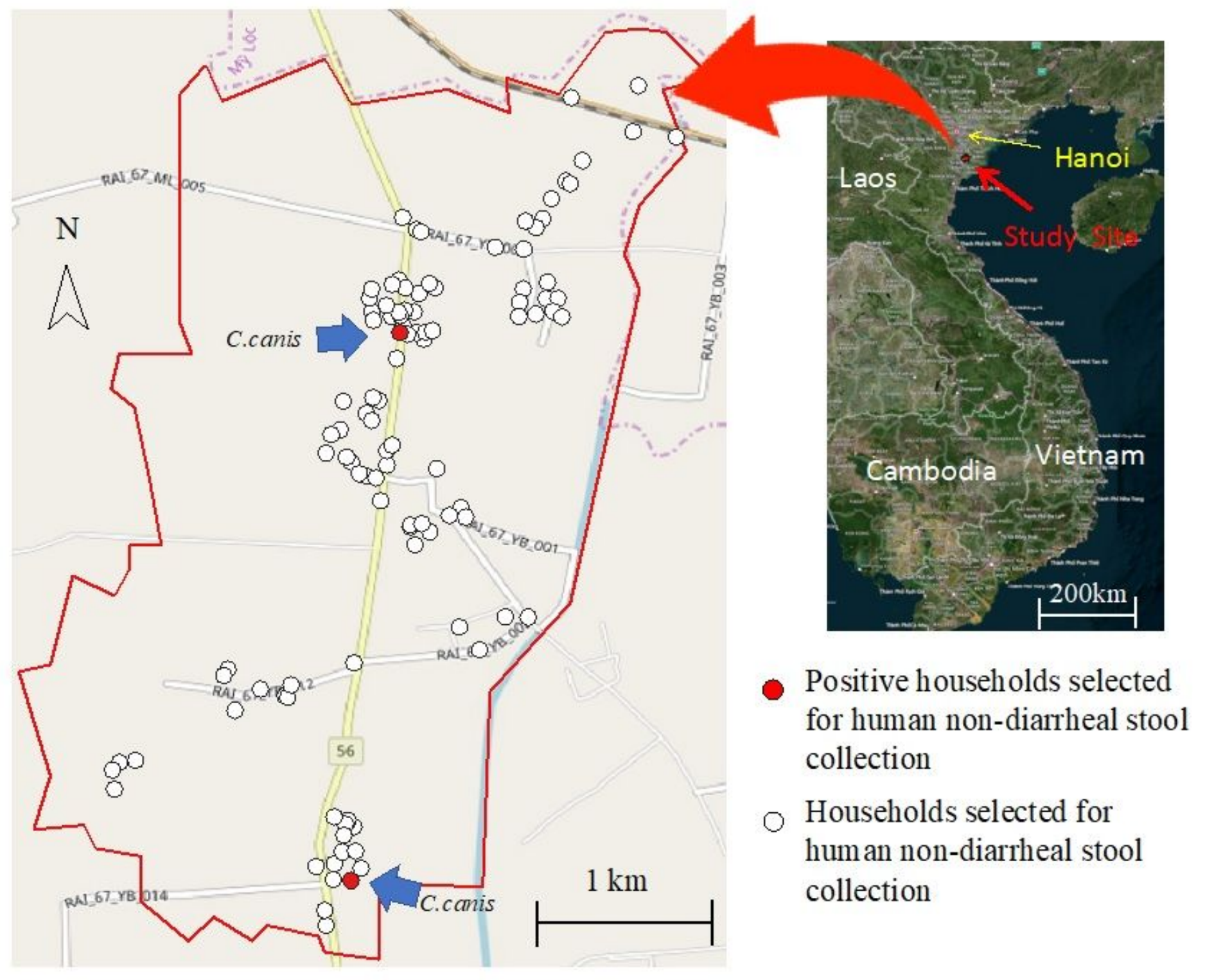

Figure 2

Collection site for human non-diarrheal stool samples. Note: The designations employed and the presentation of the material on this map do not imply the expression of any opinion whatsoever on the part of Research Square concerning the legal status of any country, territory, city or area or of its authorities, or concerning the delimitation of its frontiers or boundaries. This map has been provided by the authors. 


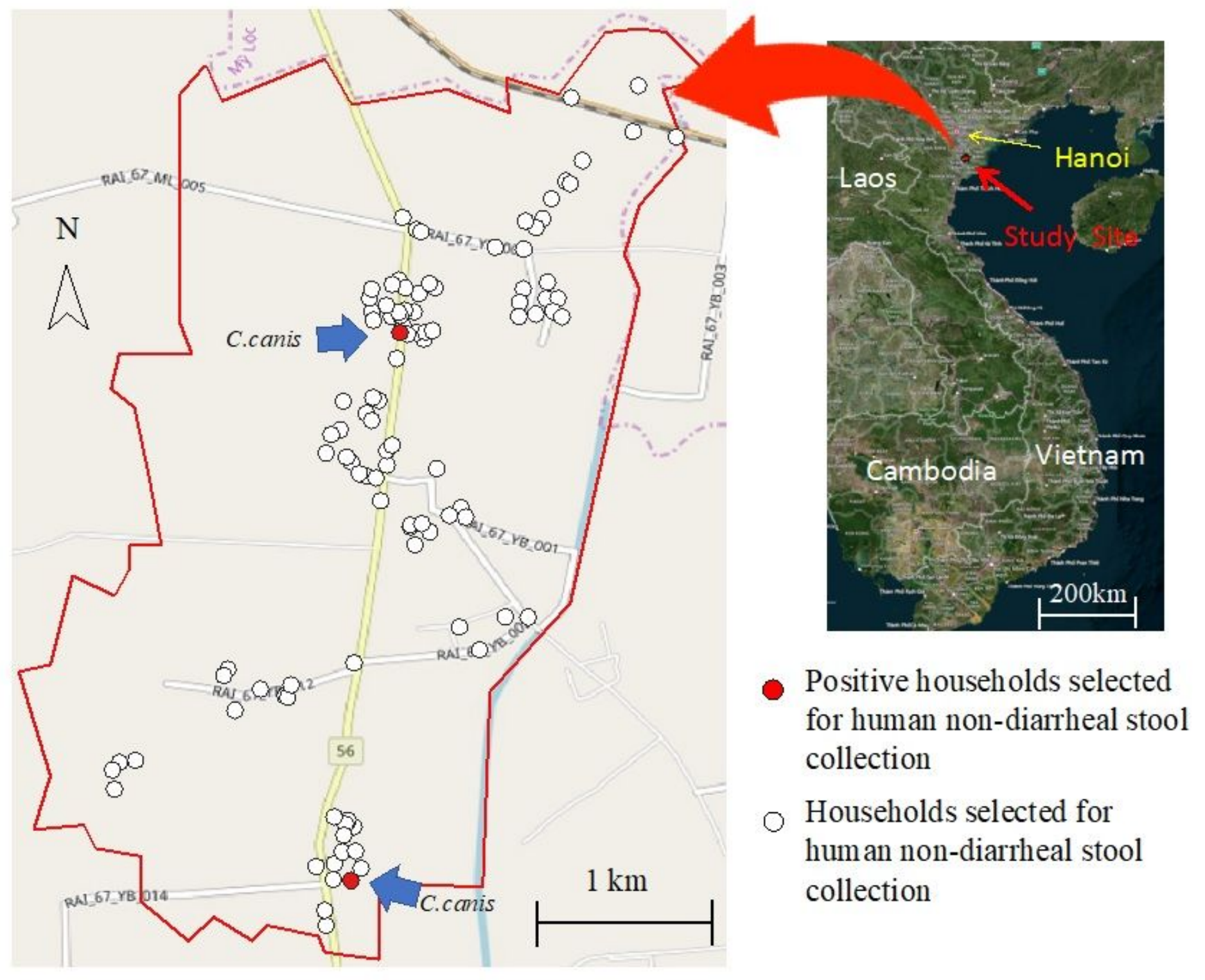

Figure 2

Collection site for human non-diarrheal stool samples. Note: The designations employed and the presentation of the material on this map do not imply the expression of any opinion whatsoever on the part of Research Square concerning the legal status of any country, territory, city or area or of its authorities, or concerning the delimitation of its frontiers or boundaries. This map has been provided by the authors. 


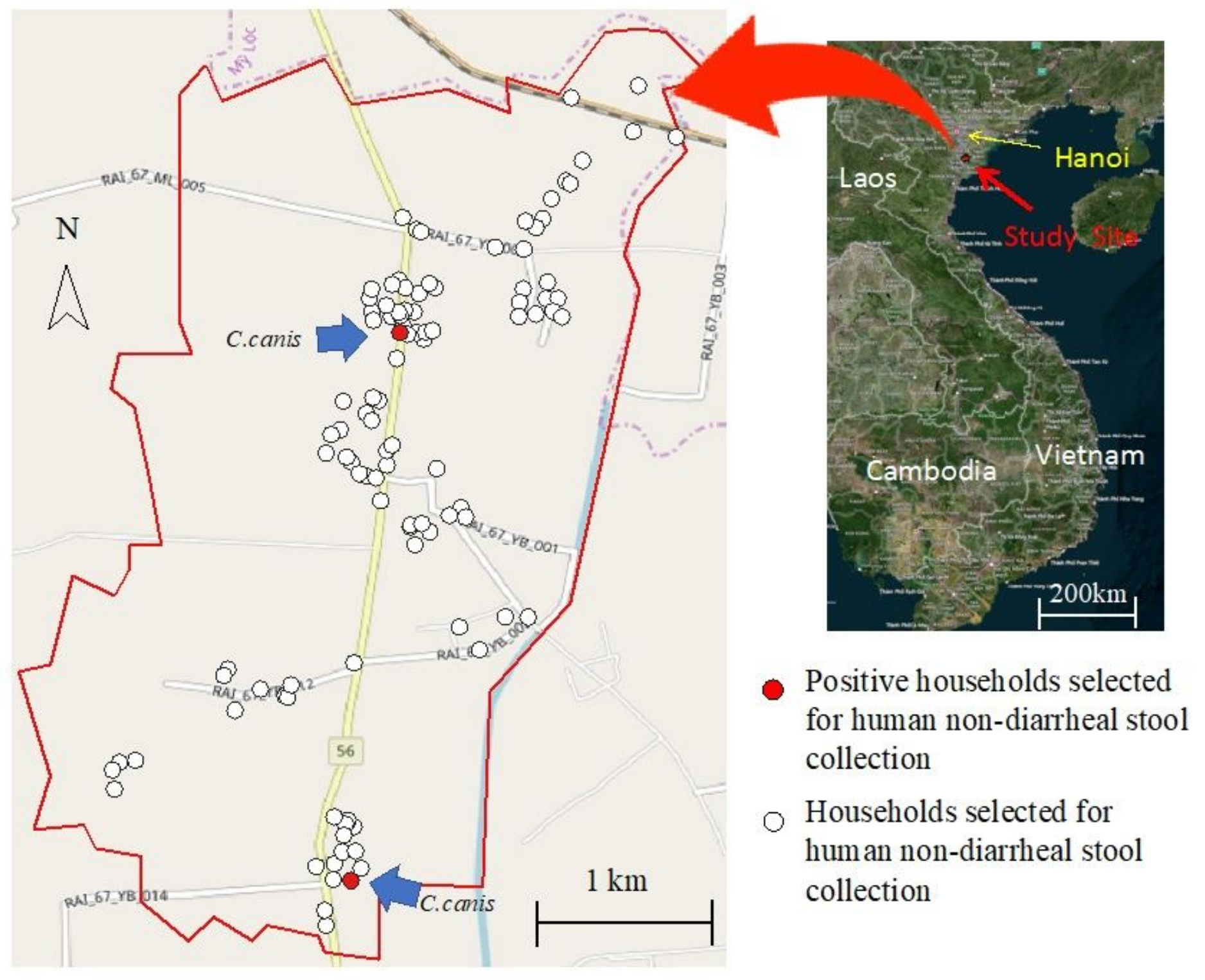

Figure 2

Collection site for human non-diarrheal stool samples. Note: The designations employed and the presentation of the material on this map do not imply the expression of any opinion whatsoever on the part of Research Square concerning the legal status of any country, territory, city or area or of its authorities, or concerning the delimitation of its frontiers or boundaries. This map has been provided by the authors. 


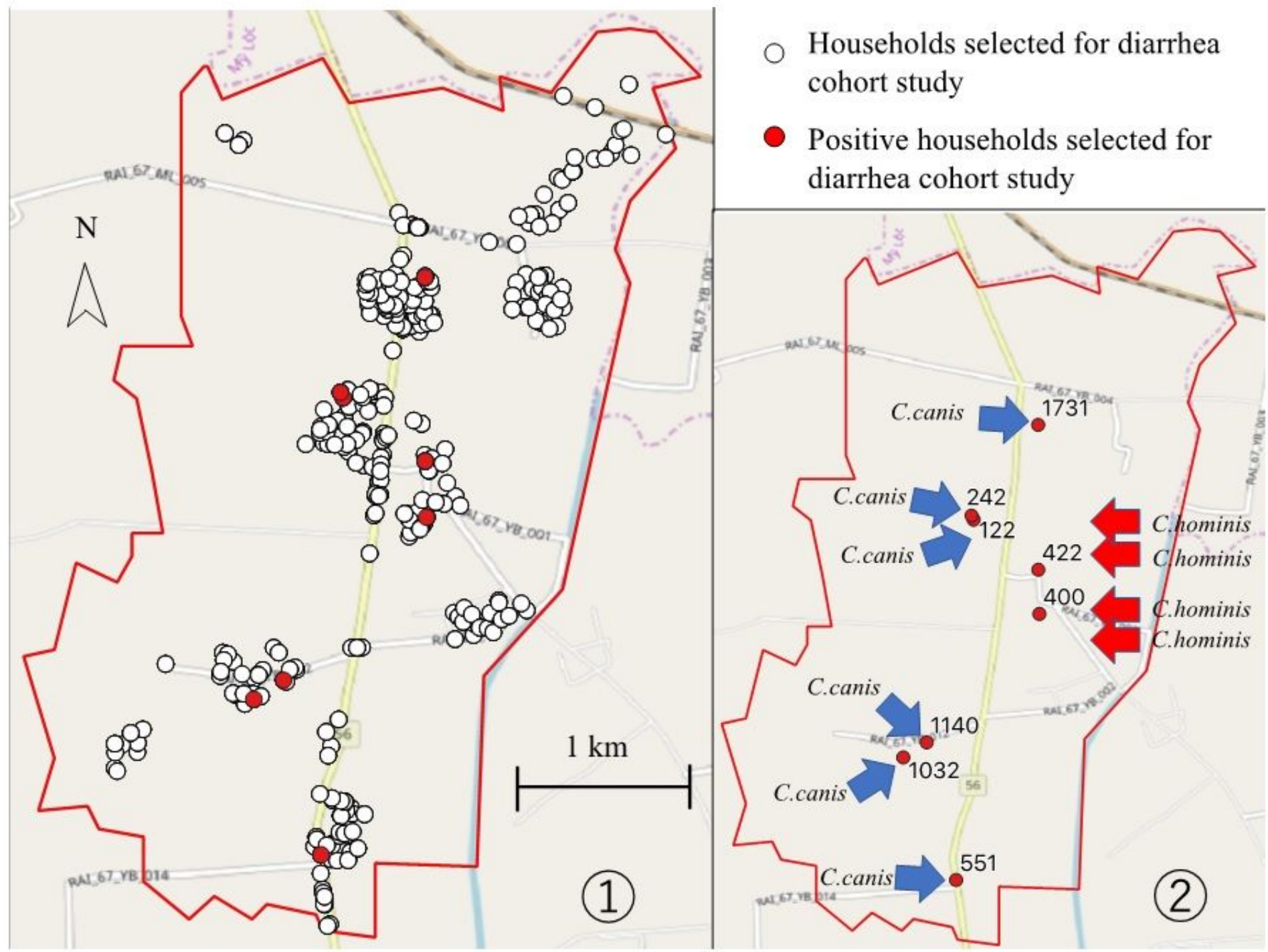

Figure 3

Collection site for human diarrheal stool samples. Note: The designations employed and the presentation of the material on this map do not imply the expression of any opinion whatsoever on the part of Research Square concerning the legal status of any country, territory, city or area or of its authorities, or concerning the delimitation of its frontiers or boundaries. This map has been provided by the authors. 


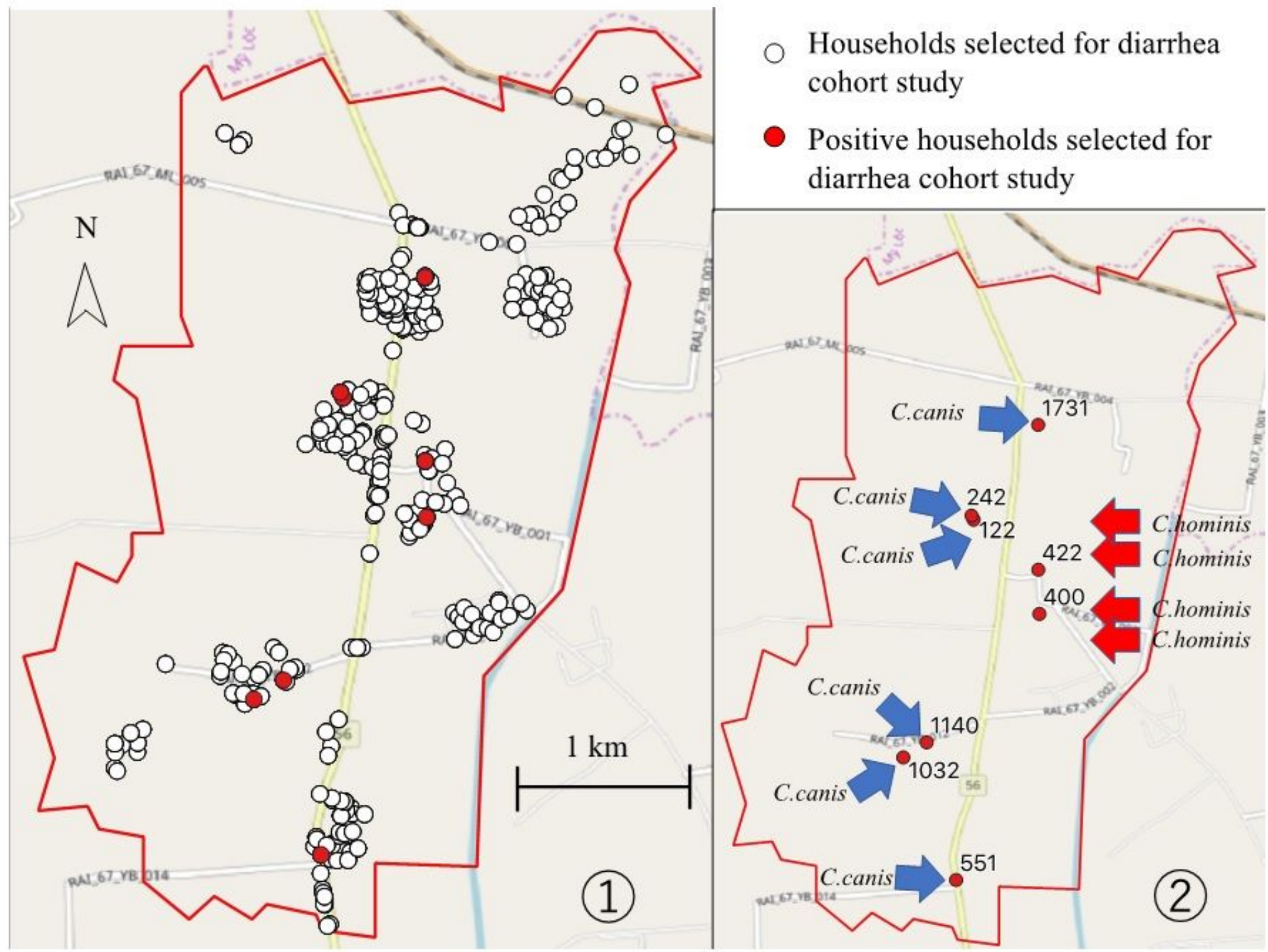

Figure 3

Collection site for human diarrheal stool samples. Note: The designations employed and the presentation of the material on this map do not imply the expression of any opinion whatsoever on the part of Research Square concerning the legal status of any country, territory, city or area or of its authorities, or concerning the delimitation of its frontiers or boundaries. This map has been provided by the authors. 


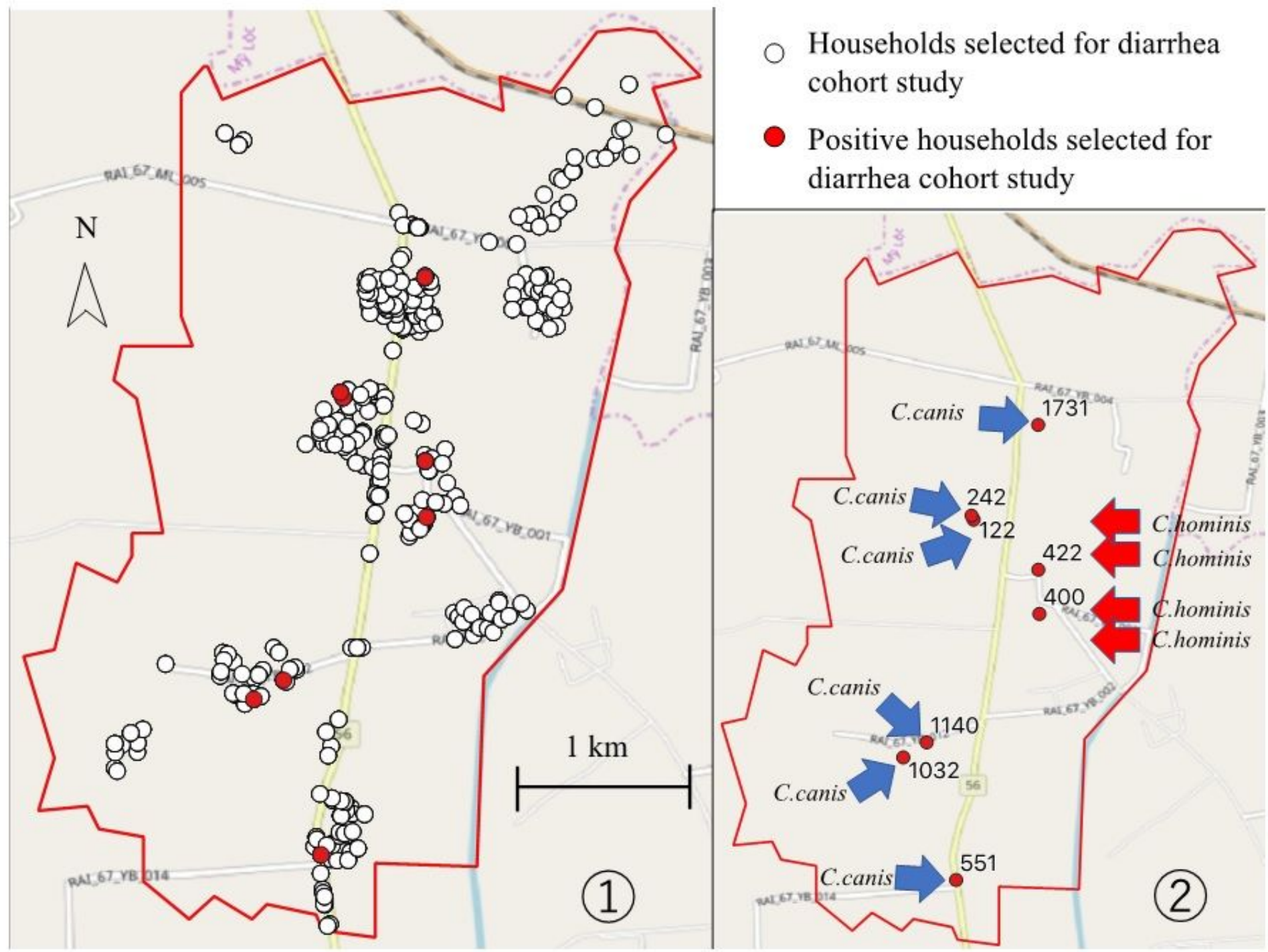

Figure 3

Collection site for human diarrheal stool samples. Note: The designations employed and the presentation of the material on this map do not imply the expression of any opinion whatsoever on the part of Research Square concerning the legal status of any country, territory, city or area or of its authorities, or concerning the delimitation of its frontiers or boundaries. This map has been provided by the authors. 


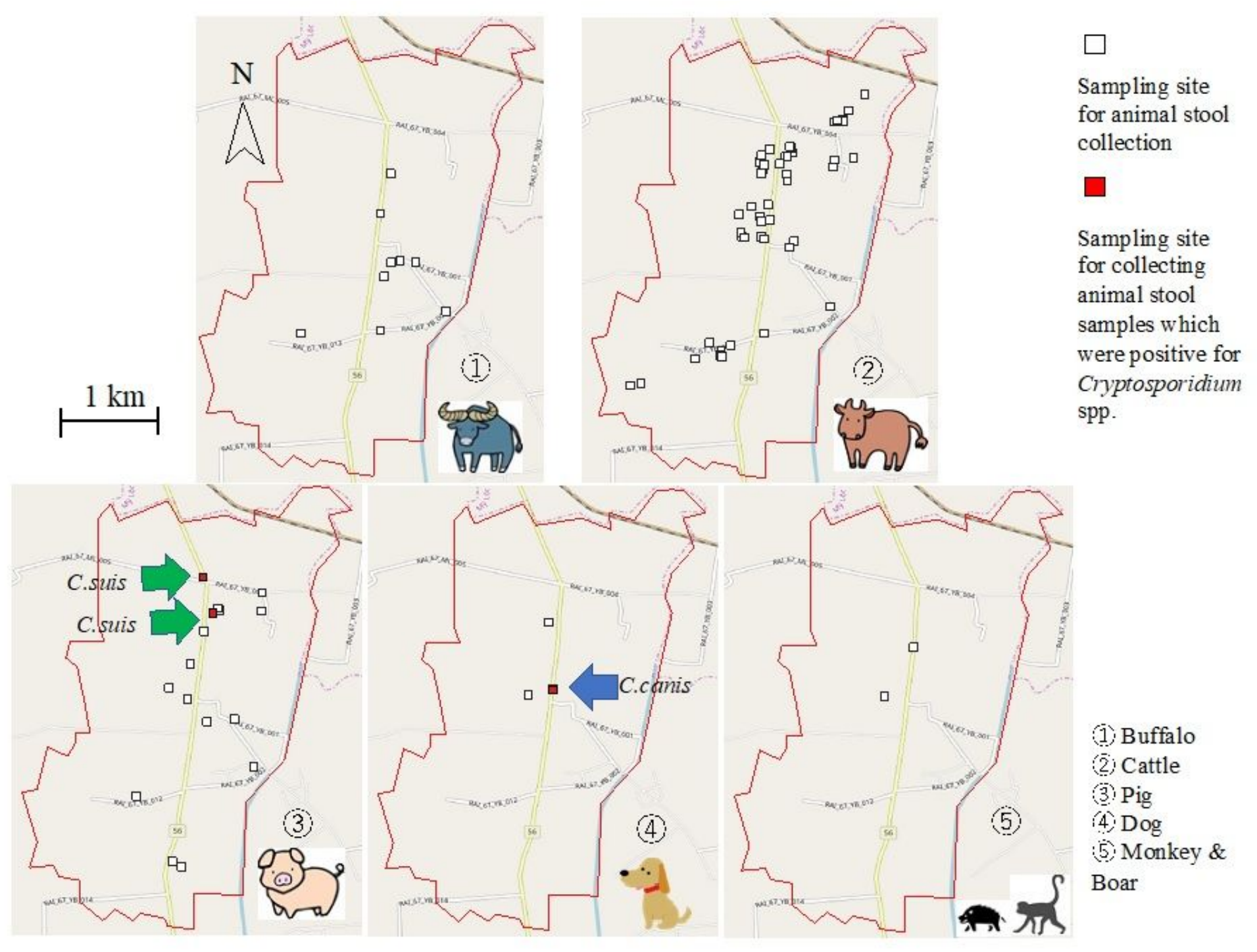

Figure 4

Collection site for animal stool samples. Note: The designations employed and the presentation of the material on this map do not imply the expression of any opinion whatsoever on the part of Research Square concerning the legal status of any country, territory, city or area or of its authorities, or concerning the delimitation of its frontiers or boundaries. This map has been provided by the authors. 


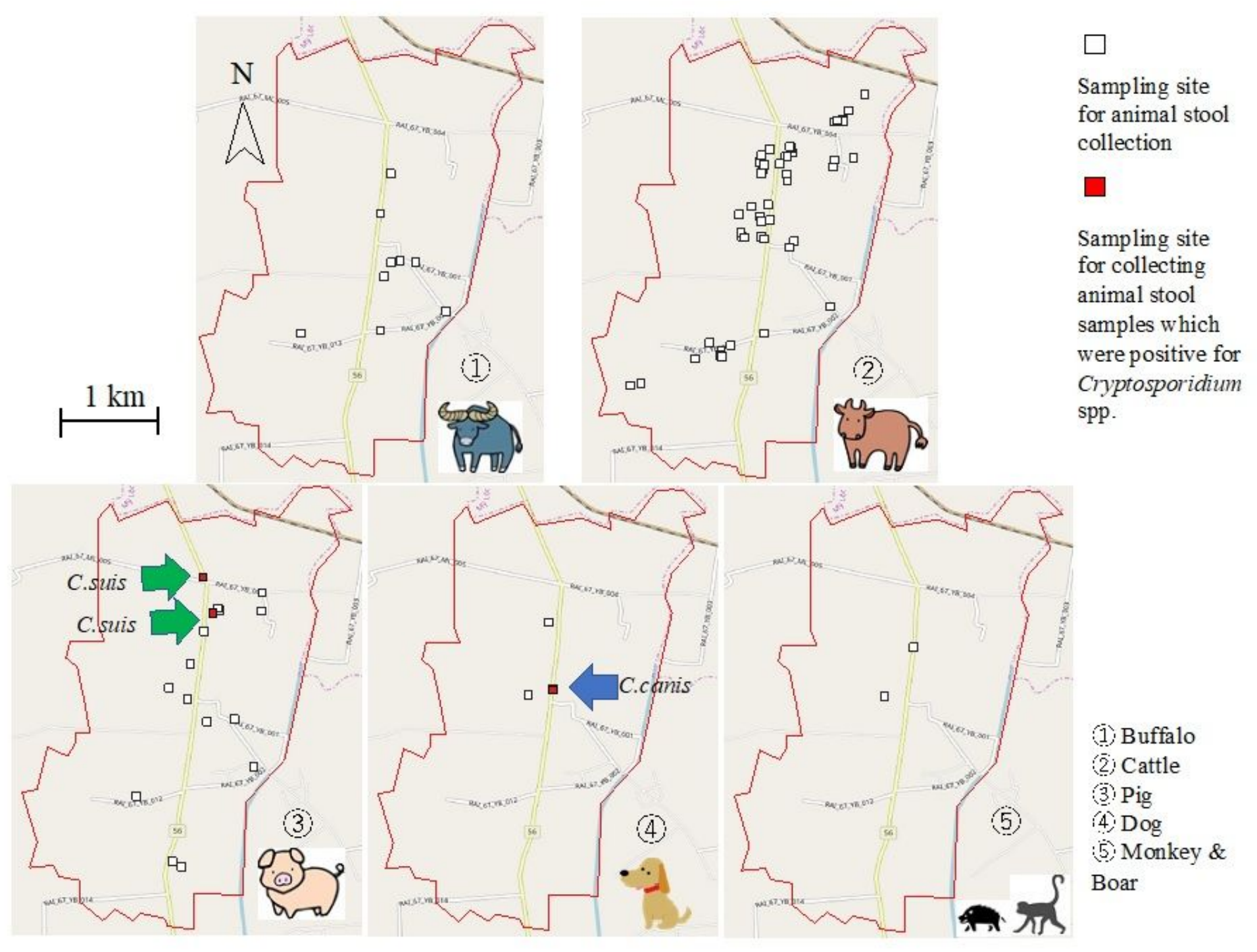

Figure 4

Collection site for animal stool samples. Note: The designations employed and the presentation of the material on this map do not imply the expression of any opinion whatsoever on the part of Research Square concerning the legal status of any country, territory, city or area or of its authorities, or concerning the delimitation of its frontiers or boundaries. This map has been provided by the authors. 


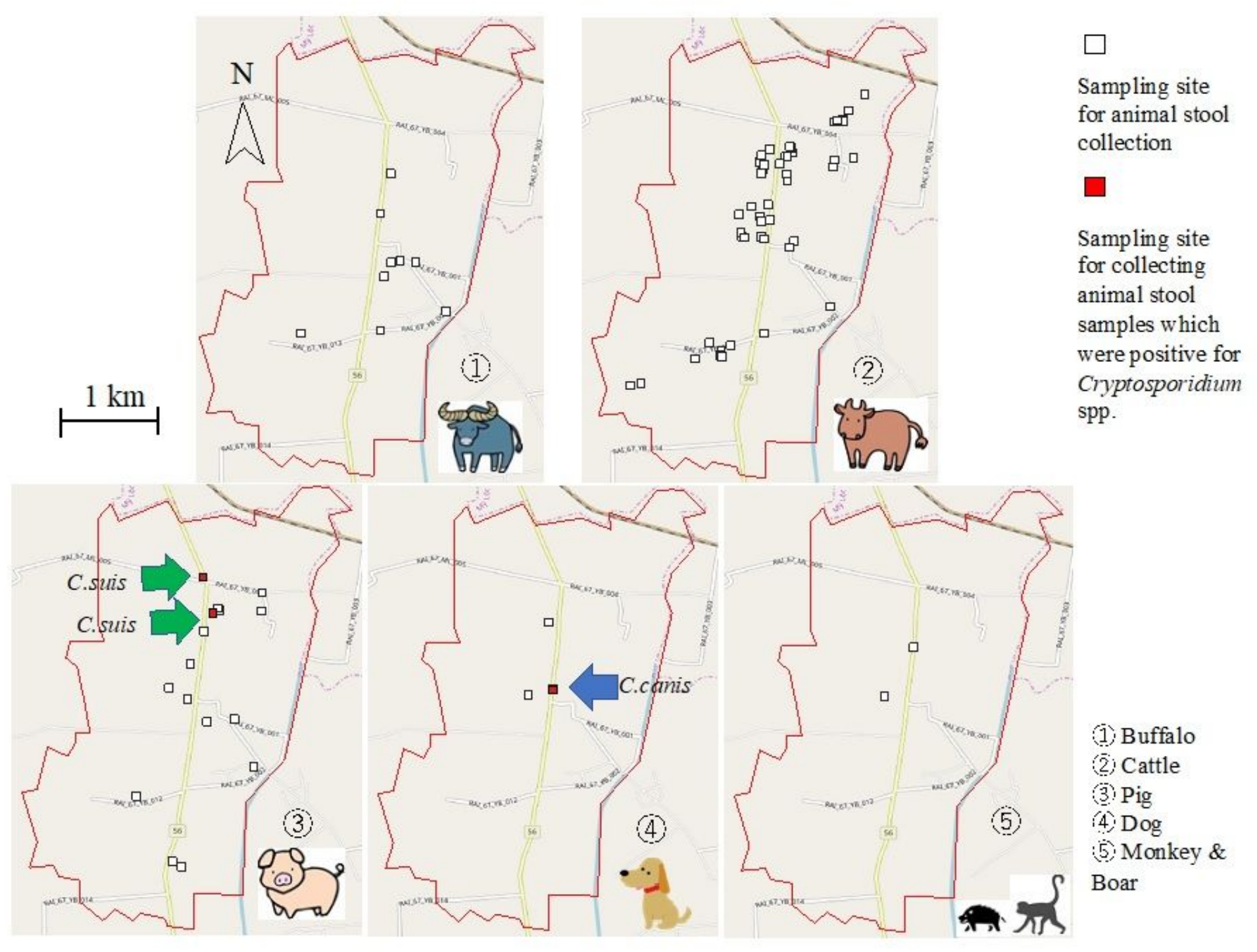

Figure 4

Collection site for animal stool samples. Note: The designations employed and the presentation of the material on this map do not imply the expression of any opinion whatsoever on the part of Research Square concerning the legal status of any country, territory, city or area or of its authorities, or concerning the delimitation of its frontiers or boundaries. This map has been provided by the authors. 


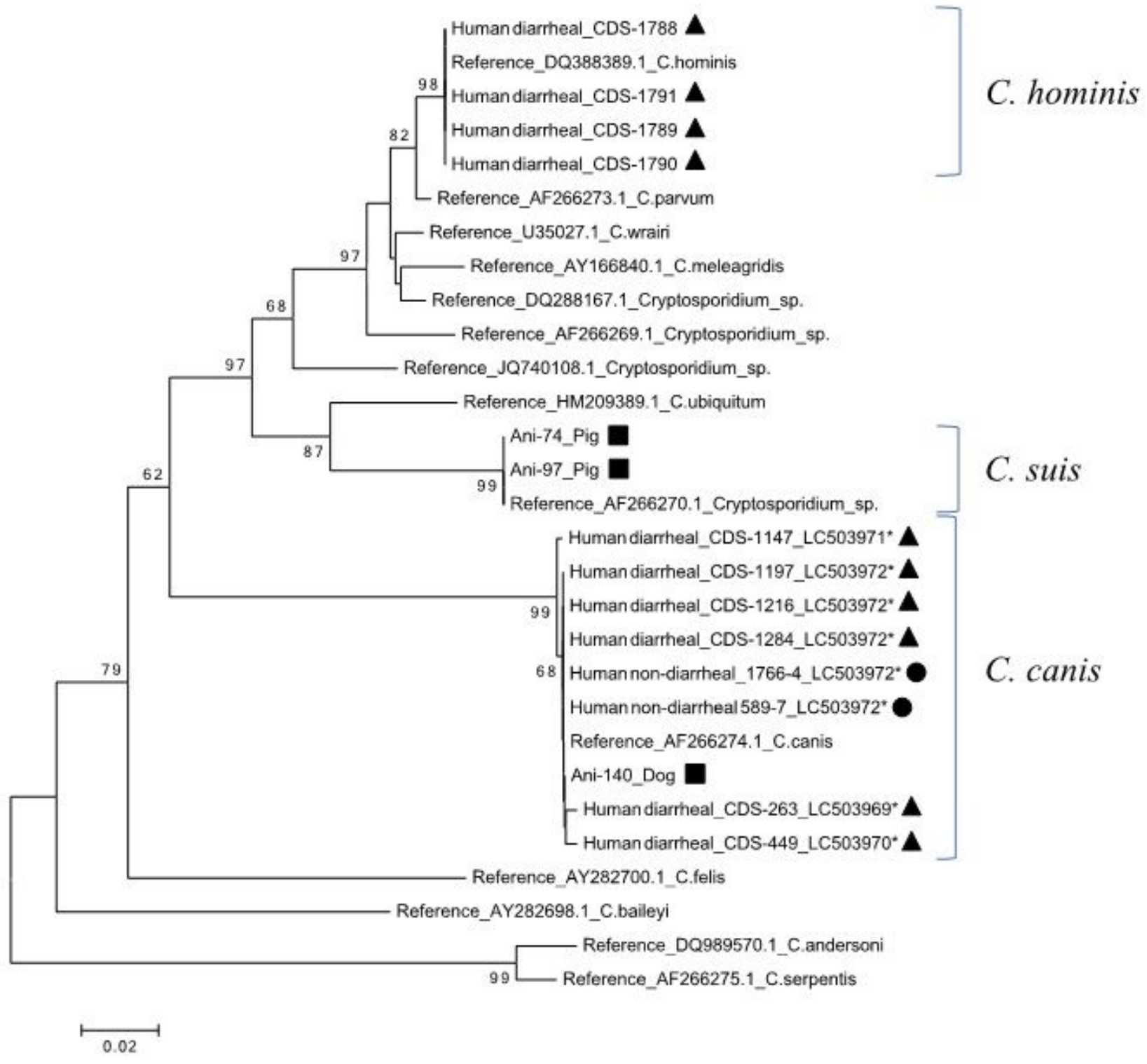

\section{Figure 5}

Phylogenetic analysis of partial COWP sequences. Filled squares, circle, and triangles represent animal, human diarrheal, and human non-diarrheal samples, respectively, from this study. Symbol (*) indicates novel sequences newly submitted to GenBank. 


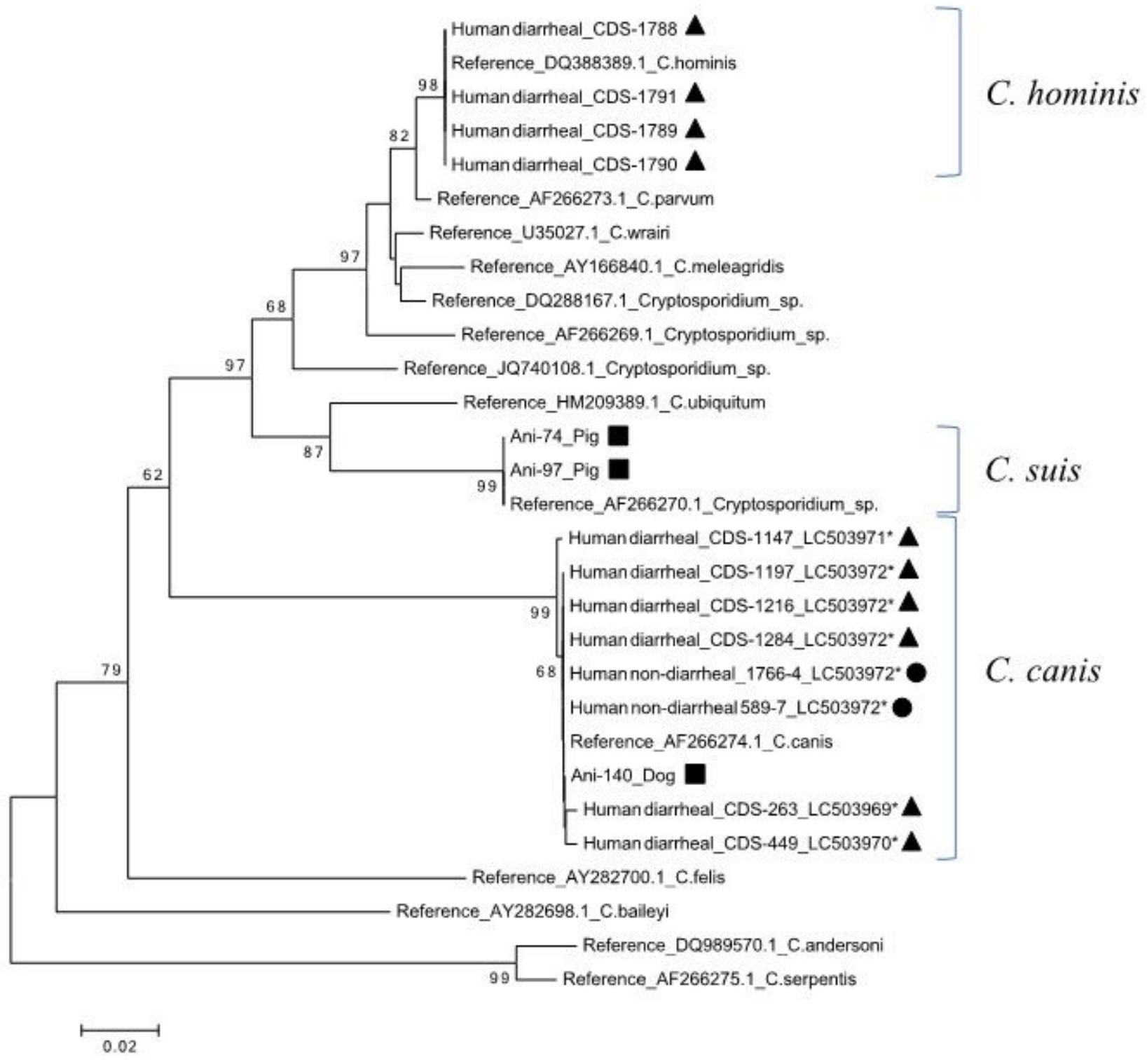

\section{Figure 5}

Phylogenetic analysis of partial COWP sequences. Filled squares, circle, and triangles represent animal, human diarrheal, and human non-diarrheal samples, respectively, from this study. Symbol (*) indicates novel sequences newly submitted to GenBank. 


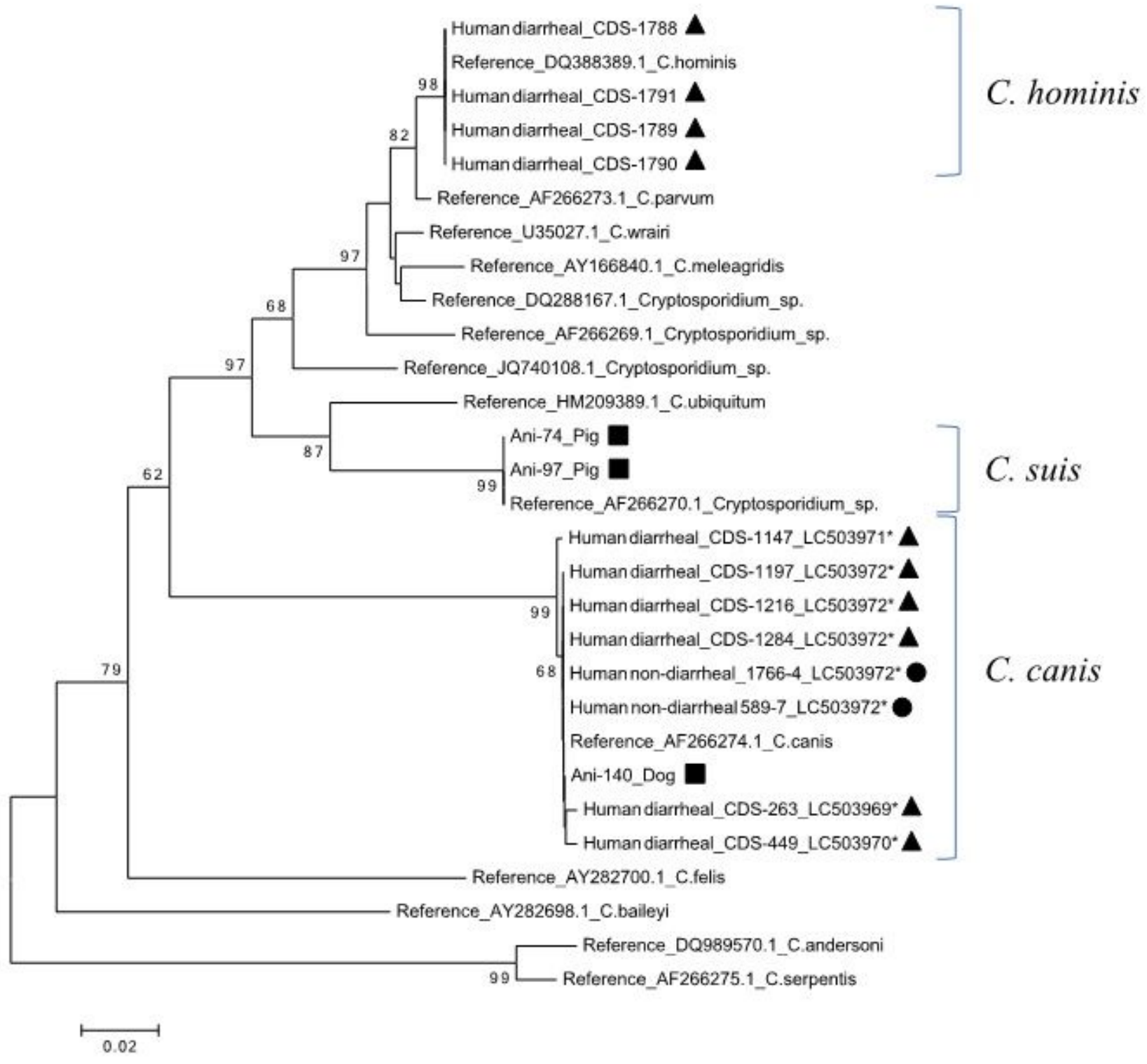

\section{Figure 5}

Phylogenetic analysis of partial COWP sequences. Filled squares, circle, and triangles represent animal, human diarrheal, and human non-diarrheal samples, respectively, from this study. Symbol (*) indicates novel sequences newly submitted to GenBank. 


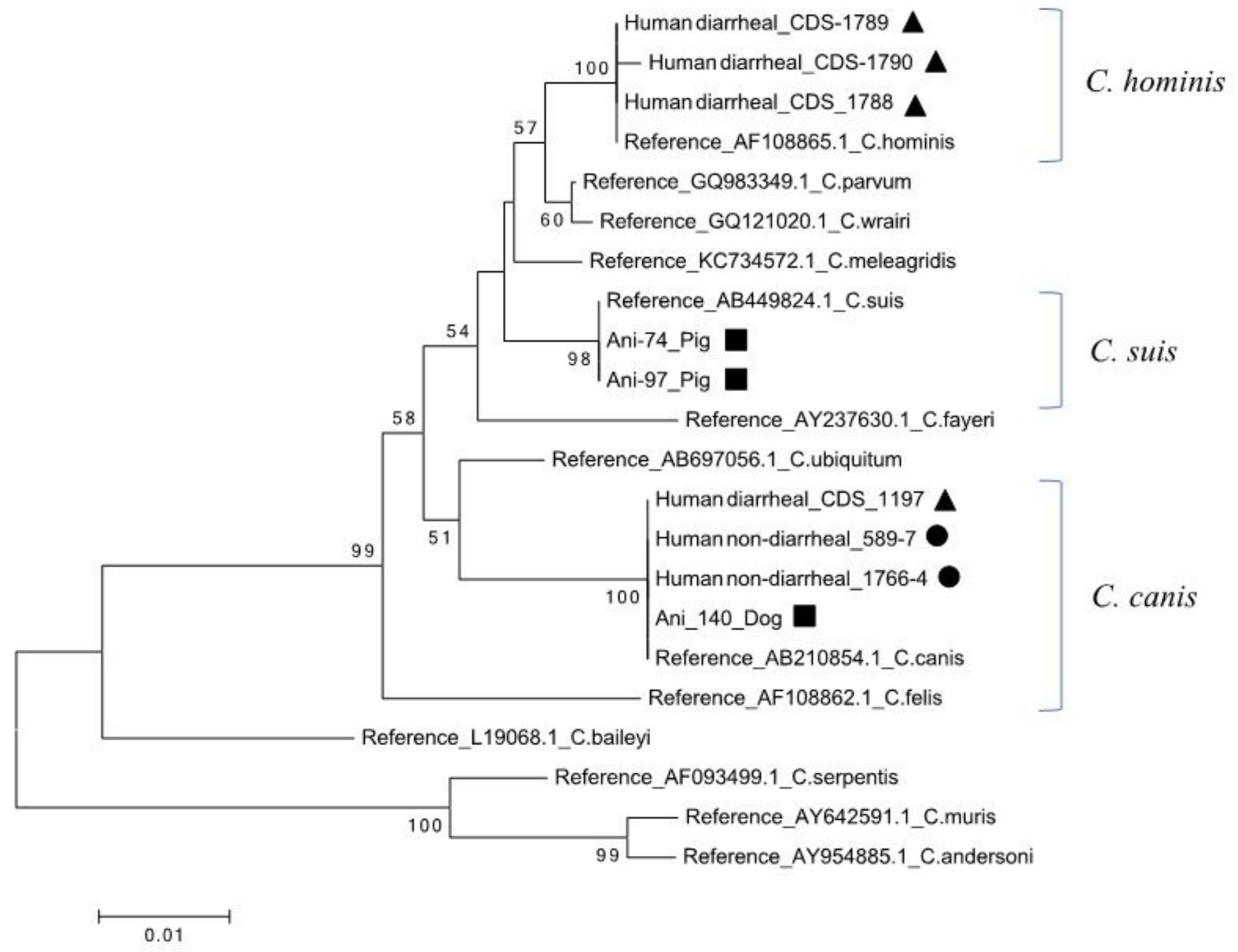

Figure 6

Phylogenetic analysis of partial SSUrRNA sequences. Filled squares, circle, and triangles represent animal, human diarrheal, and human non-diarrheal samples, respectively, from this study. Symbol (*) indicates novel sequences newly submitted to GenBank. 


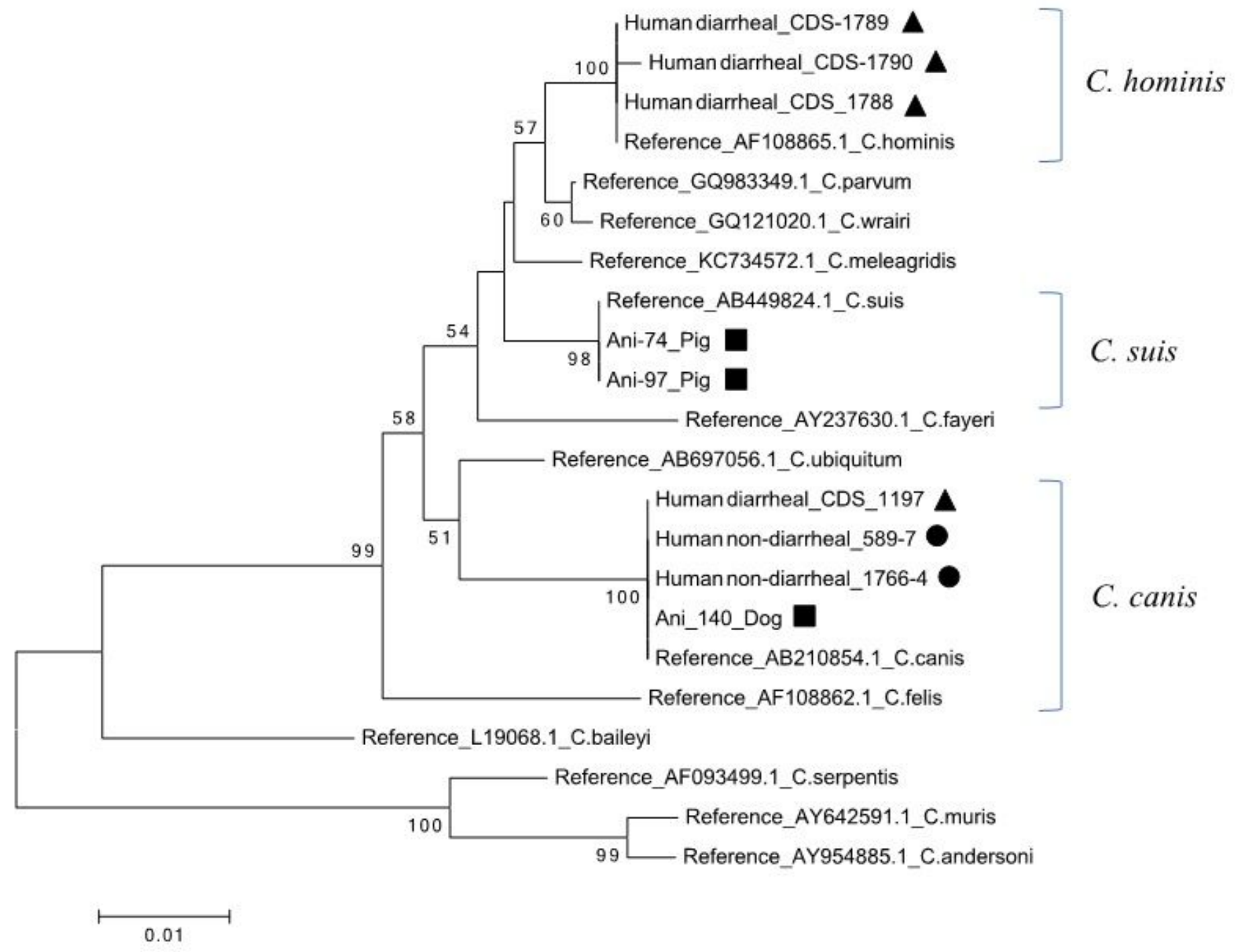

Figure 6

Phylogenetic analysis of partial SSUrRNA sequences. Filled squares, circle, and triangles represent animal, human diarrheal, and human non-diarrheal samples, respectively, from this study. Symbol (*) indicates novel sequences newly submitted to GenBank. 


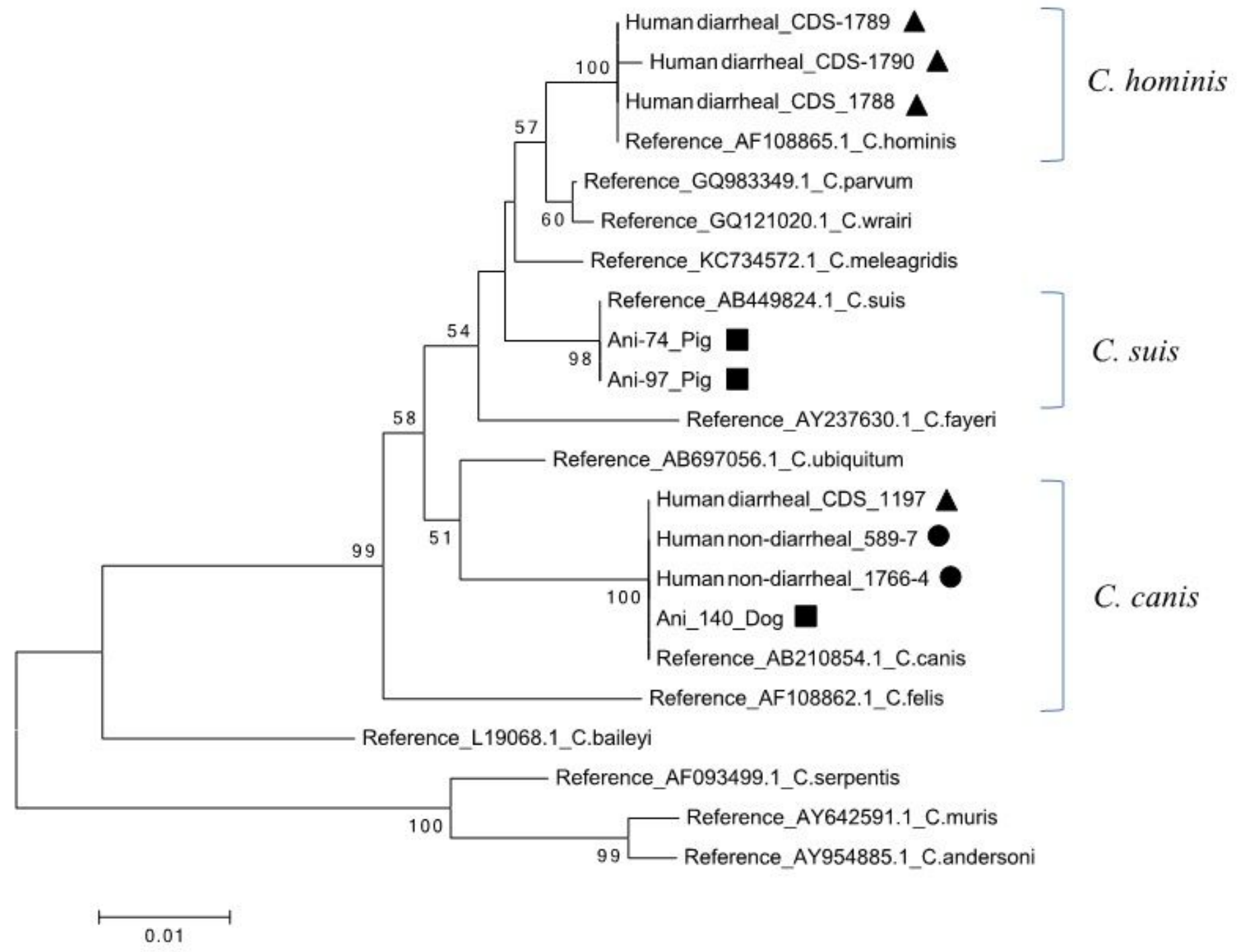

Figure 6

Phylogenetic analysis of partial SSUrRNA sequences. Filled squares, circle, and triangles represent animal, human diarrheal, and human non-diarrheal samples, respectively, from this study. Symbol $\left.{ }^{*}\right)$ indicates novel sequences newly submitted to GenBank.

\section{Supplementary Files}

This is a list of supplementary files associated with this preprint. Click to download.

- Additionalfile1TableS120201125.docx

- Additionalfile1TableS120201125.docx

- Additionalfile1TableS120201125.docx

- Additionalfile2Tables2.docx

- Additionalfile2Tables2.docx 
- Additionalfile2Tables2.docx

- Additionalfile3TableS3.docx

- Additionalfile3Tables3.docx

- Additionalfile3Tables3.docx

- Additionalfile4Tables4.docx

- Additionalfile4TableS4.docx

- Additionalfile4Tables4.docx

- Graphicalabstract20200915.docx

- Graphicalabstract20200915.docx

- Graphicalabstract20200915.docx 